\title{
Influence of Balanced Fertilization on Productivity, Nutrient Use Efficiency and Profitability of Rice in Inceptisol: A Review
}

\author{
Rahul Kumar*, Mohan Lal, R. K. Naresh, Mukesh Kumar, \\ Shipra Yadav and Rajendra Kumar, M. Sharath Chandra and Pradeep Rajput
}

Department of Agronomy, Sardar Vallabhbhai Patel University of Agriculture \& Technology, Meerut, U.P., India

*Corresponding author

\section{A B S T R A C T}

\section{Keywords}

Customised

fertilizers,

Productivity,

Profitability

Article Info

Accepted:

15 December 2019

Available Online:

20 January 2020
The decline in the rice crop responses to applied fertilizer nutrients, inter alia, could be ascribed to emerging nutrient deficiencies on account of modern era of agriculture and inadequate or imbalanced application of fertilizers. It has become increasingly recognized around the world that $\mathrm{N}, \mathrm{P}$ and $\mathrm{K}$ fertilizers alone are not always sufficient to provide balanced nutrition for optimal rice yields and quality, therefore, application of secondary and micronutrient elements has to be made. Balanced application of NPK with $\mathrm{Zn}, \mathrm{Fe}$ and $\mathrm{Mn}$ resulted in highest number of panicles, maximum panicle length and highest grain and straw yield. Das et al., (2015) recorded highest grain and straw yield with the application of S, B and $\mathrm{Zn}$ along with NPK. Application of fertilizers through SSNM i.e. application of $\mathrm{N}: \mathrm{P}: \mathrm{K}: \mathrm{Zn}: \mathrm{S}: \mathrm{B}(100: 60: 60: 25: 30: 5)$ produced at par grain and straw yield with yield obtained with the application of 150\% NPK (150:90:90). Application of $75 \%$ of nitrogen through polymer coated urea (POCU) along with $100 \% \mathrm{P}$ and $\mathrm{K}$ resulted in highest grain yield and harvest index. It is found that balanced application of NPK and Zn (100:60:60:5) resulted in higher Recovery efficiency of N, P \& K. The highest Agronomic and recovery efficiency of NPK was recorded with the application of 50\% RDF along with Nanomaterials of gypsum and rock phosphate. The highest $\mathrm{N}$ uptake and recovery efficiency in rice with the application of urea super granules @ $90 \mathrm{~kg} / \mathrm{ha}$. It can be concluded that the nutrient management through chemical fertilizers along with customised slow release fertilizer were the viable tools of improving FUE and synchronized crop demand. Therefore, balanced fertilization using chemical fertilizers of macro and micro nutrients not only has the potential to improve crop yields and farmer profits but also has positive implications on possible environmental footprint of fertilizer

\section{Introduction}

Area, production and productivity of rice is 43.79 mha, $112.91 \mathrm{mt}$ and $2.57 \mathrm{t} / \mathrm{ha}$, respectively (Anonymous, 2018). To feed the ever increasing population we need to produce more, nutrient supply is the most limiting factor for crop production, next to the water. 
Successful nutrient management can optimize crop yields, increase profitability and minimize nutrient losses. The decline in the rice crop responses to applied fertilizer nutrients, inter alia, could be ascribed to emerging nutrient deficiencies on account of modern era of agriculture and inadequate or imbalanced application of fertilizers. It has become increasingly recognized around the world that $\mathrm{N}, \mathrm{P}$ and $\mathrm{K}$ fertilizers alone are not always sufficient to provide balanced nutrition for optimal rice yields and quality, therefore, application of secondary and micronutrient elements has to be made. Comparing western U.P. and Punjab in the north and Tamil Nadu in the south, the $\mathrm{N}: \mathrm{P}_{2} \mathrm{O}_{5}: \mathrm{K}_{2} \mathrm{O}$ consumption ratio is much wider in western U.P. and Punjab (42.6:11.9:1.0) as compared to Tamil Nadu (2.6:1.0:1.0). This indicates that the highest fertilizer consuming states have the greatest imbalanced use of nutrients. The main reason of the variation in fertilizer consumption ratios in north and south is due to the nature of soils and cropping pattern. About $35 \%$ of total fertilizer is consumed by rice in India (Datta et al., 2010).

Rice production demand by 2025 will be 130 mt. About $38-40 \%$ of total fertilizers consumption accounts for rice only, heavy and imbalanced use of chemical fertilizers is causing multiple nutrient deficiency and reduced organic matter content in the soil. About 8 mha rice soils are deficient in $\mathrm{Zn}$ and 15 mha of rice soils are acidic associated with $\mathrm{Fe}$ or $\mathrm{Al}$ toxicity, depletion of bases $(\mathrm{Ca}, \mathrm{K}$, $\mathrm{Mg}$ ), P fixation and likely deficiency of B and $\mathrm{Si}$ on other hand the organic sources are insufficient for nutritional need of HYVs. Imbalanced fertilization is causing reduction in the productivity and fertilizer use efficiency of rice. Balancing the micronutrients for rice cultivation enhanced both the quality and yield of rice (Ma, 2007). Nevertheless, the availability of micronutrients such as $\mathrm{Fe}$ and $\mathrm{Zn}$ was much affected by $\mathrm{pH}, \mathrm{CaCO}_{3}$ content and soil texture. Each element of these micronutrients has its own function in plant growth (Fouly, 1983). Foliar application of micronutrients particularly $\mathrm{Zn}$ and $\mathrm{Fe}$ in small amounts had significant positive effect on 1000 grain weight, plant height, biological yield, grain yield, harvest index and oil content of sunflower (Babaeian, 2011), and growth of rice (Wissuma, 2008). The highest grain number per panicle was recorded when $\mathrm{Fe}+\mathrm{Si}$ and mixture of the three elements were applied. Meanwhile, maximum 1000 grain weight was obtained in $\mathrm{Zn}+\mathrm{Si}$ foliar application treatment. The simultaneously application of these elements had the highest biomass weight and grain yield. Also, grain yield in $\mathrm{Zn}+\mathrm{Fe}$ foliar application treatment was 9 and 13 percent greater than those in $\mathrm{Fe}$ and $\mathrm{Zn}$ treatments, respectively (Esfahani et al., 2014). Zinc deficiency has received great attention in India, because nearly half of the Indian soils are poor in availability of $\mathrm{Zn}$. The essentiality of Zn was first shown by Maze (1915) in maize, where it is known as 'white bud'. Its deficiency in rice was first reported by Nene (1966) at the Govind Ballabh Pant University of Agriculture \& Technology, Pantnagar. Rice is the bulk of food security of the global population. Rice is most susceptible to zinc deficiency. In rice cultivation, the application of micronutrient such different zinc management practices. The great sources of $\mathrm{Zn}$ such as zinc sulphate and zinc oxide $\left(\mathrm{ZnSO}_{4}\right.$ or $\left.\mathrm{ZnO}\right)$. Boron is second emerging deficient nutrient in rice tract which is affecting crop impressively. Studies on boron fertilization revealed that rice yield consistently increased with boron application. Boron may stimulate the enzymatic activity, availability of sugar and respiration which leads towards improved pollen growth. In case of severe boron deficiency, root growth of plants ceases which leads toward the death of root tips. Boron deficiency has been realized as the second most important micronutrient constraint in crops after that of zinc ( $\mathrm{Zn})$ on 
global scale. Boron deficiency has been reported to result considerable yield reduction in cereal mainly in rice. Zinc is a secondary plant nutrient which plays a significant role in increasing production and providing resistance against disease in rice crops. Zinc deficiency of lowland rice occurs widely in near-neutral to alkaline soils, particularly calcareous soils. In a severe case of zinc deficiency, transplanted rice seedlings may die or directsown seeds may fail to emerge. Sulphur is also secondary plant nutrient which plays a vital role in rice crop production as it increases root growth, seed formation and synthesis of chlorophyll. Sulphur deficiency is a common nutritional disorder in upland crops but it rarely occurs in lowland rice. A recent trend in the fertilizer industry to shift from ammonium sulphate to urea and from superphosphate to non sulphur phosphatic fertilizer may induce more widespread sulphur deficiency in lowland rice. Micronutrients are as important as macronutrients in plant nutrition and the deficiency of micronutrients is considered one of the major causes of declining the productivity trends in rice growing countries including Micronutrients are needed in trace amounts but their adequate supply improves nutrient availability and positively affects the cell physiology that is reflected in yield as well. Farmers apply N, P, K and S fertilizers widely and application of micronutrients such as $\mathrm{Zn}, \mathrm{Cu}, \mathrm{Mn}$ and $\mathrm{B}$ is not a usual practice. Soils deficient in their supply of micronutrients are alarmingly widespread across the globe due to intensive cropping, loss of fertile topsoil and losses of nutrients through leaching. When micronutrients are in short supply, the growth and yield of crops are severely depressed. The presence of micronutrient deficiency renders it impossible for the plants to gain maximum benefit from NPK fertilizers application. Micronutrient deficiency in $50 \%$ of the world's soils and many crops greatly reduces the amount and quality of food which adversely affects human health, the economic status of farmers and the environment around the world. Despite the fact that these nutrients are actively involved in various plant growth mechanisms, their specific role for yield improvement in crops is still need to be investigated. The exact effects of applying micronutrients in combination with NPK to rice crop in micronutrient deficient soils and specific climate conditions need to be better established. In order to improve crop productivity, the limiting micronutrient (s) must be identified and the soils should be enriched with the addition of those nutrients in properly balanced fertilizer programme. Keeping this in view, the present research was undertaken to investigate the effect of micronutrients viz. $\mathrm{Zn}, \mathrm{Cu}, \mathrm{Mn}$ and $\mathrm{B}$ along with NPK on growth and yield of rice. Chemical fertilizer has played a major role in the global food production over the past 60 years. It supplies about $50 \%$ of total $\mathrm{N}$ required by crops. However, its use efficiency in crop production is low (10-50\%) mainly due to loss of $\mathrm{N}$ through nitrate $\left(\mathrm{NO}_{3}\right)$ leaching, volatilization of ammonia $\left(\mathrm{NH}_{3}\right)$ and nitrous oxide $\left(\mathrm{N}_{2} \mathrm{O}\right)$ emission resulting in pollution of groundwater and atmosphere (Zhaohui et al., 2012; Galloway et al., 2003). Moreover, the production cost of nitrogen fertilizer is very high. These scenarios lead to the use technologies such as nitrogen inhibitors and slow nitrogen releasing fertilizers given as fertilizer additives to increase nutrient uptake, fertilizer use efficiencies and yields of crops (Frame and Reiter, 2013).

Slow released fertilizers, nitrification and urease inhibitors are the three possible types of products that control nitrogen loses and consequently improve nitrogen use efficiency (Schwab and Murdock, 2010). Therefore, the main aim of this paper is to review the effects of nitrogen inhibitors and slow nitrogen releasing fertilizers on crop yield, nitrogen use efficiency and mitigation of $\mathrm{N}_{2} \mathrm{O}$ emission. 
Nitrification and urease inhibitors are called nitrogen inhibitors. Nitrification inhibitors are substances that inhibit biological oxidation of ammonium to nitrate (Schwab and Murdock, 2010). Some of nitrification inhibiting products includes dicyandiamide (DCD), 3,4dimethyl-1H-pyrazoliumdihydrogen (DMPP), thiosulphate, neem, karanjin, and nitrapyrine (N-serve) (Khan et al., 2013). Exudates of some plant species have also the capacity to inhibit nitrification process in the soil (AlAnsari and Abdulkareem, 2014). Urease inhibitors are substances that inhibit conversion/hydrolysis of urea to ammonia and carbon dioxide and hence minimize ammonia volatilization losses (Schwab and Murdock, 2010). The common urease inhibitor products are phenyl phosphorodiamidate (PPD), hydroquinone (HQ), N-(n-butyl) thiophosphorictriamide (NBPT), phenyl mercuric acetate (PMA), and catechol. Controlled-released fertilizers are fertilizers such as urea that are coated with a polymer or sulfur (Khan et al., 2013). Polymer coated urea is newest and technically advanced fertilizer that gradually release nitrogen for longer time, synchronize nitrogen application to crop requirement and induce complete utilization of fertilizer for crop growth. Adequate supply of nitrogen at later growth stage improve development of yield attributes like more and longer panicle with healthy grain. Therefore the study was initiated to evaluate response of growth and yield of rice to polymer coated urea under lowland cultivation. However, monetary or economic considerations have hindered the adoption of POCU for the local farmers. The cost is more expensive to purchase POCU than NCU while POCU is primarily used on high value ornamental and nursery plants. In contrast, limited research has paid attention to economic efficiency or net economic return of $\mathrm{N}$ fertilization under an optimal $\mathrm{N}$ fertilization rate, which is major concern from rice growers (Cassman et al., 1998; Ohnishia et al., 1999;
Zhu and Chen, 2002; Ju et al., 2009; Haefele et al., 2010; Chen et al., 2011). Partial factor productivity of $\mathrm{N}$ (PFPN) and nitrogen agronomic efficiency (NAE) are useful measurements because they provide integrative indices that quantify total economic output relative to the utilization of $\mathrm{N}$ fertilizer (Cassman et al., 1996; 1998). By definition, PFPN is the grain yield obtained by per unit applied $\mathrm{N}$ under $\mathrm{N}$ fertilization without the subtraction of grain yield obtained under no-N fertilization. In contrast, a positive NAE represents a net grain yield gain under per unit applied $\mathrm{N}$ after the subtraction of grain yield under no-N fertilization. The goal of $\mathrm{N}$ fertilization is therefore to obtain maximal grain yield with optimal investment in $\mathrm{N}$ input (Haefele et al., 2010). Obviously, a higher net economic return in crop production relies on a lower cost of per unit $\mathrm{N}$ input through a higher yield. For instance, economic efficiency was greater when using three slowrelease $\mathrm{N}$ fertilizers, compared to the chemical ammonium nitrate in irrigated turfs (Arrobas et al., 2011). However, limited information is available how POCU applications could increase net economic return from rice production (Guo et al., 2010). The application of macro and micronutrients as well as use of slow release fertilizers are seems to be necessary to reduce the use of fertilizers and to improve yield and fertilizer use efficiency in rice production.

\section{Balance fertilization}

The requirement of nutrients such as Nitrogen, Phosphorus and Potash is soil and crop specific. The use of right amount and ratio of nutrients as per soil or crop requirement is known as "balanced fertilization" (J.V. Liebig). Balanced fertilization is the deliberate application of essential plant nutrients to soils that are enable to supply these nutrients in order to meet crop demand at a specific location. Balanced fertilization (BF) aims at 
nutrient supplementation in order to assist crop performance while minimizing nutrient losses. Balanced fertilization is one of the keys to improve fertilizer use efficiency, in principle, the concept of balanced fertilization aims at a dynamic balance between nutrient requirement and nutrient uptake by crops.

Panwar et al., (2019) reported that the highest productivity of RWCS with fertilizer treatments was recorded at Amritsar, except with NPK and NPK $+Z n$ fertilization, where Katni supersedes Amritsar. Application of $\mathrm{N}$ exerted a significant effect on RGEY and on an average a $106 \%$ productivity enhancement was recorded over the control across the locations. The yield improvement due to $\mathrm{N}$ application varied from $31 \%$ at Samba to $122 \%$ at Pakur over control. An approximately 3-fold productivity gain in RWCS was recorded with combined application of $\mathrm{N}$ and $\mathrm{P}$ over control across the locations; although, the increase in system productivity ranged from 83 to $265 \%$ over the control [Fig. 1].

\section{Balanced fertilization effects on crop productivity of rice}

Abid et al., (2000) reported that maximum paddy yield was exhibited by the application of NPK $+\mathrm{Mn}+\mathrm{Zn}$. Zn showed better performance in combination with $\mathrm{Mn}$ than that Fe. It was probably due to the mutual antagonism that existed between $\mathrm{Fe}$ and $\mathrm{Zn}$ as indicated by several workers (Tiwari et al., 1976: Halder and Mandal, 1981). The higher Zn (10 mg kg-1 soil) level showed more paddy yield over all other treatments when it was added in NPK and Mn. This might be due to the fact that pronounced effect of micronutrients would be expected only when the micronutrients were in the required ratio and quantity (Chaudhry and Ali, 1986).

Moe et al., (2019) also found that rice plants accumulated a large amount of DM during the tillering stage in the $\mathrm{CF}_{100}$ treatment in 2017 (Fig. 2). After that stage, DM production was similar among the $\mathrm{CF}_{100}, \mathrm{CF}_{50} \mathrm{PM}_{50}, \mathrm{CF}_{50}$ $\mathrm{CM}_{50}$, and $\mathrm{CF}_{50} \mathrm{CP}_{50}$ treatments. At harvest, the maximum DM produced was $15.01 \mathrm{t} \mathrm{ha}^{-1}$, from the $\mathrm{CF}_{50} \mathrm{PM}_{50}$ treatment, followed by $14.29 \mathrm{t} \mathrm{ha}^{-1}$ in the $\mathrm{CF}_{100}$ treatment. The amounts of $\mathrm{DM}$ produced in the $\mathrm{CF}_{50} \mathrm{CM}_{50}$ and $\mathrm{CF}_{50} \mathrm{CP}_{50}$ treatments were 12.30 and $11.26 \mathrm{t} \mathrm{ha}^{-1}$, respectively. The most DM was produced in $\mathrm{CF}_{50} \mathrm{PM}_{50}$ plots in 2018 even during the early stage. Throughout the crop period, plots treated with organic fertilizers produced DM amounts similar to those from plots treated with $\mathrm{CF}_{100}$. At harvest time, $\mathrm{CF}_{50}$ $\mathrm{PM}_{50}$ plots produced the most DM, $15.49 \mathrm{t} \mathrm{ha}^{-}$ 1. $\mathrm{CF}_{50} \mathrm{CM}_{50}$ and $\mathrm{CF}_{50} \mathrm{CP}_{50}$ also produced significantly more DM in 2017 than in 2018.

Zayed et al., (2011) revealed that the three micronutrients $\mathrm{Zn}, \mathrm{Fe}$ and $\mathrm{Mn}$ and their combinations significantly affected grain yield, straw yield and harvest index, foliar application of the comparative treatment with the three studied micronutrients twice significantly improved and increased grain and straw yields of rice. Meanwhile, the differences among $\mathrm{Zn}, \mathrm{Fe}$ and $\mathrm{Mn}$ application as single and $\mathrm{Zn}+\mathrm{Mn}$ as combination were insignificance regarding rice grain yield and harvest index. The triple combination of $\mathrm{Zn}+$ $\mathrm{Fe}+\mathrm{Mn}+$ as soil application gave the highest values of grain yield followed by the comparative foliar application treatment of the three nutrients twice. The lowest values of rice grain yield was recorded when rice plant did not receive any of the applied micronutrients. Gomaa et al., (2015) reported that the application of micronutrients fertilization resulted in higher grain yield and led to a significant increase in $\mathrm{Zn}$ and $\mathrm{Fe}$ concentrations in rice grains. The highest mean values of $\mathrm{Zn}$ and $\mathrm{Fe}$ concentrations were produced by application of mixture $(\mathrm{Zn}+\mathrm{Fe})$ when compared with the untreated. 
Suresh and Salakinkop (2016) reported that the soil application of $\mathrm{ZnSO}_{4}$ and $\mathrm{FeSO}_{4}$ each (a) $25 \mathrm{~kg} \mathrm{ha}^{-1}$ recorded significantly higher grain and straw yield $\left(3575 \mathrm{~kg} \mathrm{ha}^{-1}\right.$ and 5299 $\mathrm{kg} \mathrm{ha}^{-1}$, respectively) compared to lower levels of $\mathrm{ZnSO}_{4}$ and $\mathrm{FeSO}_{4}$ each @ 10, 15 and $20 \mathrm{~kg}$ $\mathrm{ha}^{-1}$ and control (2878 and $3718 \mathrm{~kg} \mathrm{ha}^{-1}$, respectively. Increased yield due to $\mathrm{Zn}$ and $\mathrm{Fe}$ application was attributed to better performance of growth and yield parameters through adequate availability of major and micro nutrients in soil, which in turn, favourably influenced physiological processes and build-up of photosynthates (Tabassum et $a l ., 2013)$. There was increased grain yield of 16.5 per cent upon application of $2.5 \mathrm{~kg} \mathrm{Zn} \mathrm{ha}{ }^{-}$ 1; while 15 per cent upon application of $5.0 \mathrm{~kg}$ $\mathrm{Zn} \mathrm{ha}^{-1}$ in rice (Rahman et al., 2006).

Siddika et al., (2016) stated that the grain yield of rice was significantly influenced due to different treatments and was recorded highest with the application of NPKS $+\mathrm{Zn}+\mathrm{Cu}$, application of micronutrients in association with NPKS showed better performance in respect of grain yield and yield contributing characters viz. plant height, number of effective tillers hill $^{-1}$, number of grains panicle $^{-1}$ and dry matter yield of rice as compared to the application of NPKS only. The performance of $\mathrm{Zn}+\mathrm{Cu}$ with NPKS was the best for improving the growth and yield of rice. Therefore, application of $\mathrm{Zn}$ at $1 \mathrm{~kg} \mathrm{ha}^{-1}$ and $\mathrm{Cu}$ at $2 \mathrm{~kg} \mathrm{ha}^{-1}$ in association with NPKS fertilizers could be the promising combination for maximizing rice yield. Cuong et al., (2017) stated that most of the yield components (such as number of grains per panicle, seed-setting rate and 1000-grain weight), grain yield and straw yield were significantly affected by $\mathrm{Si}$ application. Number of grains per panicle was increased by almost $6 \%$ under $\mathrm{RDF}+400$ $\mathrm{kg} / \mathrm{hm}^{2} \quad \mathrm{SiO}_{2}$ treatment compared with the control. Seed-setting rate was $89.8 \%$ under the highest dose of $\mathrm{Si}$ and RDF, whereas it was $80.2 \%$ for the control. Similarly, 33\% increase in 1000-grain weight was recorded for RDF + $400 \mathrm{~kg} / \mathrm{hm}^{2} \mathrm{SiO}_{2}$ compared with only RDF treatment. There was about $23 \%$ increase in grain yield and nearly $20 \%$ increase in straw yield for $\mathrm{RDF}+400 \mathrm{~kg} / \mathrm{hm}^{2} \mathrm{SiO}_{2}$ compared with the control.

Kumar et al., (2017) reported progressive increase the grain and straw yield of transplanted rice which increased significantly with different sources of zinc over control. However, maximum grain yield $\left(7.11 \mathrm{t} \mathrm{ha}^{-1}\right)$ and straw yield $\left(8.45 \mathrm{t} \mathrm{ha}^{-1}\right)$ were recorded with@soil application of $50 \mathrm{~kg} \mathrm{ZnSO}_{4} \mathrm{ha}^{-1}$, this treatment was statistically at par with soil application of $\mathrm{ZnO}$ equivalent to $50 \mathrm{~kg} \mathrm{ZnSO}_{4}$ $\mathrm{ha}^{-1}$ and Seedling dip in $\mathrm{ZnO}$ Slurry equivalent to $10 \mathrm{~kg} \mathrm{ZnSO}_{4} \mathrm{ha}^{-1}$ [Table 1]. This might be due to increased transplantation of photosynthate from source to sink due to zinc application as reported by Varsheny (1988). Superiority of soil application of $50 \mathrm{~kg} \mathrm{ZnSO}_{4}$ $\mathrm{ha}^{-1}$ over other treatments might be attributed due to higher zinc concentration alone with availability of sulphur which resulted more number of productive tillers, filled grains panicle $^{-1}$ and higher test weight which ultimately increased grain and straw yield in soil application of $50 \mathrm{~kg} \mathrm{ZnSO}_{4} \mathrm{ha}^{-1}$ followed by soil application of $\mathrm{ZnO}$ equivalent to $50 \mathrm{~kg}$ $\mathrm{ZnSO}_{4} \mathrm{ha}^{-1}$, seedling dip in ZnO Slurry equivalent to $10 \mathrm{~kg} \mathrm{ZnSO}_{4} \mathrm{ha}^{-1}$ The results corroborate with the findings of Singh and Sharma (1994).

Mohan et al., (2017) reported that the maximum growth and yield of rice with the application of $100 \% \mathrm{RDF}+2$ foliar spray of $10 \mathrm{~kg} \mathrm{ZnSO}_{4} \mathrm{ha}^{-1}+5 \mathrm{~kg} \mathrm{FeSO} 4 \mathrm{ha}^{-1}+10 \mathrm{~kg}$ Borax ha ${ }^{-1}+10 \quad \mathrm{~kg}$ Sulphur ha ${ }^{-1}$ was significantly superior over rest of the treatments at all the stages of crop growth. It is due to fact that balanced dose of nutrients is responsible for the better growth of crop. Similar results have also been reported by Lin and Lin (1985) and Desmukh et al., (1988). 
Pasha et al., (2018) also found that the application of recommended dose of $\mathrm{NPK}+\mathrm{ZnSO}_{4}$ recorded significantly higher grain yield over years and lowest with control. However, the treatments recommended NPK and farmers practice were registered at par on average grain yield to that of $\mathrm{NPK}+\mathrm{ZnSO}_{4}$ [Table 2]. Rice grain equivalent yield was also with recommended dose of $\mathrm{NPK}+\mathrm{ZnSO}_{4}$ $\left(5.80 \mathrm{tha}^{-1}\right)$. However, sustainable yield index (SYI) was higher with recommended dose of NPK followed by farmer's practice and recommended dose of $\mathrm{NPK}+\mathrm{ZnSO}_{4}$. Control treatment registered lowest SYI.

\section{Customised fertilizers effects on nutrient use and productivity of rice}

Bulbule et al., (2006) also found that briquettes at rates of $28,56,84$ and $112 \mathrm{~kg}$ $\mathrm{N} / \mathrm{ha}$ in a single dose after transplanting in modified spacing of $15-25 \times 15-25 \mathrm{~cm}$. The results revealed distinct superiority of briquettes over the conventional fertilizer (prilled urea) under the prevailing conditions. The yields of rice consistently increased when the crop was fertilized through briquettes (56 $\mathrm{kg} \mathrm{N} / \mathrm{ha}$ ) compared to the application of $\mathrm{N}$ through conventional fertilizer(100 kg N/ha). Placement of briquettes in modified spacing of $15-25 \times 15-25 \mathrm{~cm}$ at lower rates at an extra cost is certainly affordable to farmers since it offsets the additional cost through substantial increase in grain yields $(25-30 \%)$ at lower levels of fertilizer. Mendhe et al., (2006) revealed that increase in plant height, number of tillers/plant, dry matter accumulation/plant, effective tillers/plant, number of grains/ panicle, grain yield (34.02q/ha) and straw yield (45.90 q/ha) due to the application of UB-DAP (@ $56: 14 \mathrm{~kg}$ ) at trans planting+25\% $\mathrm{N}$ at panicle initiation, over the only organic manure FYM @ 5 t/ha at the time of transplanting (26.90 and $36.31 \mathrm{q} / \mathrm{ha})$. Bhagat et al., (2005) revealed that application of recommended fertilizer dose of NPK
(100:50:50 $\mathrm{kg} / \mathrm{ha})$ through briquettes, significantly influenced the height of plant, test weight of grain, grain and straw yield (44.28 and 59.78q/ha, respectively). This was found effective in improving all growth and yield attributes along with yield of grains and straw. Bowen et al., (2005) reported that the yield increase under urea deep placement was achieved using much less urea fertilizer. Urea deep placement resulted in higher grain yield and $\mathrm{N}$ fertilizer use efficiency than FP. The average urea deep placement grain yield benefit over FP was $1120 \mathrm{~kg} / \mathrm{ha}$ during the boro season and $890 \mathrm{~kg} / \mathrm{ha}$ during the aman season.

Jagtap et al., (2011) reported that, the grain yield of rice was significantly influenced due to various fertilizer sources. Among all these sources, treatment receiving urea-DAP briquettes gave higher grain yield (49.29, 53.04and $51.17 \mathrm{q} / \mathrm{ha}$ during the year 2009-10 and pooled mean, respectively) followed by urea-suphala briquettes which were at par with each other but found significantly superior to RDF. The treatments receiving urea-suphala briquettes and RDF were at par with each other during both the years and in the pooled mean. The mean increase in grain yield recorded under the application of urea-DAP briquettes over urea-suphala briquettes and application of RDF was to the tune of 3.89 and $8.06 \%$,respectively. The increase in grain yield of rice due to application of urea- DAP briquettes maybe accounted for significant improvement in yield attributes viz., number of panicles/hill, length of panicle, number of filled grains/panicle, weight of filled grains/panicle and test weight which finally resulted in increased grain yield.

Rajani and Sen (2017) concluded that the low solubility and synchronized release of nitrogen are the important characteristics of polymer coated urea that ensures single (co-situs) application of entire recommended dose of 
nutrient at a time. At same amount of nitrogen polymer coated urea improved plant height, tiller numbers, grains per panicle and grain yield by $8.51 \%, 24.33 \%, 16.07 \%$ and $23.37 \%$ respectively, over uncoated urea at harvesting. Highest grain and straw yield (24.17 and $31.08 \mathrm{q} \mathrm{ha}^{-1}$ respectively) was observed under polymer coated urea (double layer). It is confirmed from the findings of experiment that polymer coated urea is one of the best fertilizer for rice grower for producing higher and sustainable yield with minimum cultivation cost.

\section{Balanced fertilization and fertilizer use efficiency}

Patil et al., (2010) reported that highest grain yield and partial factor productivity was recorded with application of fertilizer mixture of FM-N56:C28 (FM-25:13:13, NPK). Kumar et al., (2014) studied the effect of nanofertilizers on nutrient use efficiency in rice and reported that the highest recovery efficiency, agronomic efficiency and grain yield was recorded with the application of $50 \%+$ Nanomaterials of gypsum and rock phosphate @ $3 \mathrm{~kg} / \mathrm{ha}$ as soil application. Dhane et al., (2002) indicated that use of UB-DAP with improved management practice increased the rice grain yield by $37 \%$ over control with $44 \%$ saving in recommended dose of fertilizer. Powar and Deshpande (2001) observed that the grain yield obtained with deep placement of UB-DAP was at par with that of broadcast application of PU+SSP. Mishra et al., (1998) observed that NUE with urea briquette (UB) +PU @ 30 kg/ha each (46.4q/ha and 35.50\%) were significantly superior over broadcast and split application 60kg $\mathrm{N}$ through PU. Dafterdar and Savant (1995) reported that simply deep placement of either urea briquette (UB) or UB-DAP at $7-10 \mathrm{~cm}$ soil depth (1briquette per 4 hills) immediately after transplanting with modified $20 \times 20 \mathrm{~cm}$ spacing substantially increased the grain yield
(4.55 t/ha) and straw yield (6.67 t/ha) of rice compared to conventional practice of split application of PU, basal application of SSP by broad cast method (2.29 and $4.54 \mathrm{t} / \mathrm{ha})$ at the same level of $\mathrm{N}$ and $\mathrm{P}$ application.

Battacharya et al., (2014) conducted an experiment to study of effect of nutrient rate on nutrient use efficiency in rice and revealed that balanced application of NPK and Zn (100:60:60:5) resulted in higher Recovery efficiency of N, P \& K. However, the highest grain yield was obtained with the application of NPK and Zn (100:75:75:5). The lowest grain yield was recorded in control treatment. Li et al., (2015) reported that the grain yield of rice was influenced by $\mathrm{N}$ fertilizer type and $\mathrm{N}$ input level. Averaged over years and $\mathrm{N}$ levels, greater annual grain yields were significantly ranked as under POCU > under NCU > under control (11.4, 10.6 and $7.2 \mathrm{Mg} \mathrm{ha}{ }^{-1}$, respectively) [Table 3].

Liu et al., (2016) reported that the highest yield (91.6 $\mathrm{g} \mathrm{hill}^{-1}$ ) was observed when 210 $\mathrm{mg} \mathrm{N} \mathrm{kg}{ }^{-1}$ soil was applied as basal fertilizer, which was a $14.6 \%$ improvement on FFP (79.9 $\mathrm{g} \mathrm{hill}^{-1}$ ) [Fig. 4]. However, treatment yields when $\mathrm{N}$ was applied as a jointing or panicle fertilizer were all lower than FFP regardless of $\mathrm{N}$ rate.

Li et al., (2015) stated, Nitrogen use efficiency and NAE are major indicators of $\mathrm{N}$ efficiency in the field (Moll et al.,1982; Weih et al., 2010). In general, 20-40\% of NUE and 10-20 $\mathrm{kg}$ grain $\mathrm{kg}^{-1} \mathrm{~N}$ of NAE could be improved by the decrease of $\mathrm{N}$ supplement to rice in the Chinese paddy soils (Cassman et al., 2002; Zhu and Chen, 2002; Wang et al., 2007; Huang et al., 2008; Zhang et al., 2008; Peng et al., 2010). Results of this study indicated that POCU application had significantly higher aboveground biomass (yield plus straw), NUE, NAE and PFP N compared to NCU, both in the early and late rice (Table 3 ). These 
advantages of POCU over NCU might be that the $\mathrm{N}$ release from POCU could synchronize to plant $\mathrm{N}$ requirement (Shoji and Kanno, 1994; Xu et al., 2005). Some reports showed that the use of POCUs can be related to an improvement of $\mathrm{N}_{2}$ fixation in flooded rice (Carreres et al., 2003) and the reduction in nutrient concentration in runoff water (Emilsson et al., 2007). In addition, the applications of POCU increased the residual $\mathrm{N}$ in the soil compared to NCU, particularly in the late growth period of rice (Soon et al., 2011), resulting in higher $\mathrm{N}$ uptake in rice. As a consequence, NUE was increased and $\mathrm{N}$ losses was decreased under POCU (Xu et al., 2013). One of the best management procedures for NCU was to split its application at different crop growth stages, although it was difficult to operate and labour intensive (Patil et al., 2010). Nevertheless, one time application of POCU was similar to the two or three split applications of NCU in terms of yield and reduction of $\mathrm{N}$ loading in the environment (Shaviv and Mikkelsen, 1993; Patil et al., 2010; Soon et al., 2011).

\section{Balanced fertilization and economics}

Bulbule et al., (2006) reported that placement of briquettes (in modified spacing15-25 x 15$25 \mathrm{~cm}$ ) at lower rates at an extra cost was certainly affordable to farmers since it offset the additional cost through substantial increase in grain yields $(25-30 \%)$ at lower levels of fertilizer. Ghodke et al., (2008) reported that maximum gross returns (Rs. 47251.19/ha), net returns (Rs. 11181.58/ha) and B : C ratio (1.31) were observed with urea-DAP briquettes treatment as compared to different levels of recommended dose of fertilizers. Darade (2007) revealed that the placement of urea-DAP briquettes $+50 \quad \mathrm{kgK}_{2} \mathrm{O} / \mathrm{ha}$ realized the maximum net returns of Rs. 25268.92/ha with highest B: C ratio of 2.23. Kumar et al., (2017) revealed that soil application of $50 \mathrm{~kg}$ $\mathrm{ZnSO}_{4} \mathrm{ha}^{-1}$ recorded to highest net return of
Rs. 82607 followed by foliar application twice with $0.2 \% \mathrm{ZnSO}_{4}$ (Rs. 72627) and seedling dip in $\mathrm{ZnO}$ slurry equivalent to $10 \mathrm{~kg} \mathrm{ZnSO}_{4}$ $\mathrm{ha}^{-1}$ (Rs.71577) [Table 4]. Highest benefit cost ratio (BCR) of 2.34 were recorded treatment, soil application of the $50 \mathrm{~kg} \mathrm{ZnSO}_{4} \mathrm{ha}^{-1}$ followed by foliar application twice with $0.2 \%$ $\mathrm{ZnSO}_{4}$ and seedling dip in $10 \mathrm{~kg} \mathrm{ZnSO} 4$ slurry $\mathrm{ha}^{-1}$ recording to 2.23 and 2.10 (BCR) respectively. These result could corroborated with findings of Varsheney et al., (2008).

Chen et al., (2011) reported that improper input of excessive $\mathrm{N}$ fertilizer to rice field could result a low return due to the high loss. This can be verified from the dry matter production (Fig.5). Total $84.87 \mathrm{t}$ dry matters were produced per hectare in $\mathrm{FN}$ in three years with total $\mathrm{N}$ input of $1530 \mathrm{~kg}$. The dry matter production per $\mathrm{kg} \mathrm{N}$ fertilizer was $0.055 \mathrm{t}$ for FN treatment, $0.067-0.068 \mathrm{t} \mathrm{kg}^{-1}$ for $\mathrm{OCN}$, RCN and CRU treatments, and further increased to $0.074 \mathrm{t} \mathrm{kg}^{-1}$ for SSNM treatment when the $\mathrm{N}$ application decreased by about $35 \%$.

Singh and Singh (2017) reported that to produce optimum rice yields, amount and time of application of fertilizer $\mathrm{N}$ be governed by the amount and pattern of organic $\mathrm{N}$ mineralized after "flooding. The rice production systems that lack controlled water management and undergo several alternate aerobic and anaerobic shifts during a crop season show inefficient $\mathrm{N}$ use because substantial amounts of applied as well as native soil $\mathrm{N}$ are preferentially lost via denitrification. The most fundamental $\mathrm{N}$ recommendation for lowland rice is to use ammonical or $\mathrm{NH}_{4}{ }^{+}$forming fertilizers such as urea. Ammonium $\mathrm{N}$ may be lost through volatilization, fixed by clay minerals, or immobilized by soil organic matter (Fig.6). The $\mathrm{NO}_{3}{ }^{-}$containing fertilizer sources should not be applied prior to soil submergence as $\mathrm{NO}_{3}{ }^{-}-\mathrm{N}$ may get denitrified or lost via 
leaching, particularly on permeable sandy soils or may possibly be transported in the general direction of water movement across a field (Buresh et al.,2008). As $\mathrm{NH}_{4}^{+}$, a cation, attaches to the soils cation exchange complex and is held by the soil very close to its point of placement, $\mathrm{NH}_{4}{ }^{+}$fixation capacity of a soil should be taken into account when strategies for $\mathrm{N}$ fertilization are developed to maximize $\mathrm{N}$-use efficiency.

Pasha et al., (2018), among the different treatments tested, cost of cultivation was highest (Rs $75290 \mathrm{ha}^{-1}$ ) with farmer's practice and was lowest in control (Table 5). Recommended dose of $\mathrm{NPK}+\mathrm{ZnSO}_{4}$ resulted in higher gross (Rs $164740 \mathrm{ha}^{-1}$ ) and net return (Rs $902600 \mathrm{ha}^{-1}$ ) with a cost of cultivation of Rs. $74480 \mathrm{ha}^{-1}$ and was followed by recommended dose of NPK with Rs 156620 $\mathrm{ha}^{-1}$ of gross returns and Rs $86600 \mathrm{ha}^{-1}$ of net returns. However, Benefit Cost ratio was higher in recommended dose of NPK (2.24) due to less cost of cultivation (Rs $70020 \mathrm{ha}^{-1}$ ) when compared with recommended dose of $\mathrm{NPK}+\mathrm{ZnSO}_{4}$ (2.21). In farmers practice the cost of cultivation was high when compared to other NPK combinations but the productivity was lesser than recommended NPK with or without $\mathrm{ZnSO}_{4}$, hence resulted lower net returns and $\mathrm{B}: \mathrm{C}$ ratio.

Likewise in control, though cost of cultivation was less due to no fertilizer application, this treatment recorded lesser grain yield and net benefit was also the lowest. These results are in agreement with findings of Sharma et al., (2011). Hiremath and Hosamani (2015) in their study on maize-chickpea system stated that recommended dose of NPK along with $\mathrm{ZnSO}_{4}$ recorded significantly higher net returns and benefit cost ratio than other treatments. Singh et al., (2017) also confirmed that application of recommended quantity of nitrogen, phosphorus and potassium together with supplementation of location specific deficient micronutrient enhanced marginal returns in cereal based cropping systems.

Yu et al., (2019) revealed that long-term balanced fertilization increases the soil microbial functional diversity in a phosphorus-limited paddy soil, chemical fertilization significantly increased the diversity and abundance of most genes involved in $\mathrm{C}, \mathrm{N}, \mathrm{P}$ and $\mathrm{S}$ cycling, especially for the treatments NK and NPK.

Significant correlations were found among functional gene structure and abundance, related soil enzymatic activities and rice yield, suggesting that a fertilizer-induced shift in the microbial community may accelerate the nutrient turnover in soil, which in turn influenced rice growth. The effect of $\mathrm{N}$ fertilization on soil microbial functional genes was mitigated by the addition of $\mathrm{P}$ fertilizer in this P-limited paddy soil, suggesting that balanced chemical fertilization is beneficial to the soil microbial community and its functions.

Jahan et al., (2019) showed their findings and concluded that in both AEZs, 'STB' fertilizer management with CRI resulted in the highest gross return (26823 \& 49530 Rs ha $\left.{ }^{-1}\right)$, followed by 'STB' (52085 \& $\left.49246 \mathrm{Rs} \mathrm{ha}^{-1}\right)$, 'IPNS+CRI' (51375\& $48466 \mathrm{Rs} \mathrm{ha}^{-1}$ ), and 'IPNS' (51091 \& $48182 \mathrm{Rs} \mathrm{ha}^{-1}$ ), due to higher yields in those treatments (Table 6).

With some exceptions, similar trends were also found for gross margin and net returns. In both AEZs, due to higher yields, BCR was also higher in STB management (251 \& 238), followed by 'STB+CRI' (237 \& 226) and 'IPNS' (231 \& 219).

Similarly, MBCR was also highest for 'STB' (743 \& 723) followed by 'STB+CRI' (598 \& 573 ), due to comparatively lower variable costs. Control plots, on the other hand, 
resulted in the lowest gross returns, gross margin, net returns and BCR due to low yield (Table 6).

These results indicate that the overall economic performance of the aforesaid $T$. aman rice is sustainable with ' $\mathrm{STB}$ ', 'STB+CRI' and 'IPNS' management. Other researchers (Jahan et al., 2016 and Hossain et al., 2016) also reported similar results for different cropping patterns and without CRI.

Prices: rice grain, 9.22 $\mathrm{Rs} \mathrm{kg}-1$; rice straw, $0.22 \mathrm{Rs} \mathrm{kg-1}$. Labour: Rainfed monsoon rice, 110-120 people (labourwage 71-106 Rs person-1 day-1). Fertilizers and manure: urea (N), 5.67-6.39 Rs kg-1; triple super phosphate (P), 16.32-17.74 Rs kg-1; murate of potash (K), 13.48-14.19 Rs kg-1; gypsum (S), 4.25$56.76 \mathrm{Rs} \mathrm{kg-1;}$ zinc sulphate $(\mathrm{Zn}), 57.47-$ 60.31 Rs kg-1; cowdung, 0.28-0.35 Rs kg-1 $\mathrm{BCR}=$ Benefit-cost ratio; $\mathrm{MBCR}=$ Marginal benefit-cost ratio HYG'; High Yield Goal, 'MYG'; Moderate Yield Goal, 'IPNS'; Integrated Plant Nutrient System, 'STB'; Soil Test Based, 'FP'; Farmer's Practice, 'CON'; without fertilizers, 'CRI': crop residue incorporation.

This review paper emphasized the role and importance of balanced fertilization i.e. major and micro inorganic nutrient sources as a management strategy that can bring sustainability to the rice crop of the Indian subcontinent. Micro nutrients improve chemical properties of a soil but the nutrients may not be as readily available to the plants. Inorganic fertilizer is usually immediately and fast containing all necessary nutrients that are ready for plants. The excess use of inorganic fertilizers in agriculture can lead to soil deterioration, soil acidification and environment pollution. The balanced plant nutrient management system is an alternative approach for the sustainable and cost-effective management of soil fertility and is characterized by reduced input of inorganic fertilizers and combined use of inorganic macro nutrient fertilizers with micro nutrient materials. Balanced applications of macro and micro nutrients improve soil fertility, productivity and reduce the impact of heavy use of inorganic fertilizers on environment.

So, it is an alternative way for sustainable soil fertility and productivity. On the basis of foregoing discussion it can be concluded that balanced use of fertilizers along with slow release fertilizers and nutrient release inhibitors enhanced the productivity of rice.

Combined application of micronutrients, nutrient inhibitors with $100 \%$ RDF resulted in good growth parameters, yield attributes, significantly higher yield, grain quality of rice.

Integrated use of macro and micro nutrient provide the scientific basis for balanced fertilization not only between the fertilizer nutrients themselves but also that with the soil available nutrients. Moreover, the nutrient management through chemical fertilizers alongwith customised slow release fertilizer were the viable tools of improving fertilizer use efficiency and synchronized crop demand.

Therefore, balanced fertilization using chemical fertilizers of macro and micro nutrients not only has the potential to improve crop yields and farmer profits but also has positive implications on possible environmental footprint of fertilizer use. 
Table.1 Effect of different sources of Zinc on protein content, yield and nutrient uptake of rice crop (Kumar et al., 2017)

\begin{tabular}{|c|c|c|c|c|c|}
\hline Treatments & $\begin{array}{c}\text { Grain } \\
\text { yield } \\
\left(\text { t ha }^{-1}\right)\end{array}$ & $\begin{array}{c}\text { Straw } \\
\text { yield } \\
(\mathrm{t} \mathrm{ha-1})\end{array}$ & $\begin{array}{c}\text { Total N } \\
\text { uptake } \\
\left(\mathrm{kg} \mathrm{ha}^{-1}\right)\end{array}$ & $\begin{array}{l}\text { Zn Uptake } \\
\text { by grain } \\
\left(\mathbf{k g ~ h a}^{-1}\right)\end{array}$ & $\begin{array}{l}\text { Protein } \\
\text { content } \\
(\%)\end{array}$ \\
\hline$T_{1}:$ No zinc application & 5.70 & 7.00 & 107.50 & 0.79 & 6.87 \\
\hline $\begin{array}{c}\mathrm{T}_{2}: \text { Soil application of the } 50 \mathrm{~kg} \mathrm{ZnSO4} \\
\mathrm{ha}^{-1}\end{array}$ & 7.11 & 8.45 & 146.34 & 1.06 & 7.43 \\
\hline $\begin{array}{c}\mathrm{T}_{3}: \text { Soil application of } \mathrm{Zn} \text { equivalent } 50 \\
\operatorname{kg~} \mathrm{ZnSO} 4 \mathrm{ha}^{-1}\end{array}$ & 6.74 & 7.82 & 120.35 & 0.89 & 7.31 \\
\hline $\begin{array}{c}\mathrm{T}_{4} \text { : Seedling dip in } 10 \mathrm{~kg} \mathrm{ZnSO4} \text { slurry } \\
\mathrm{ha}^{-1}\end{array}$ & 6.17 & 7.20 & 115.81 & 0.9 & 7.12 \\
\hline 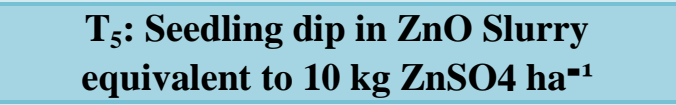 & 6.47 & 7.40 & 123.39 & 0.93 & 7.25 \\
\hline $\begin{array}{c}\mathrm{T}_{6}: \text { Foliar application twice with } 0.2 \% \\
\text { ZnSO4 }\end{array}$ & 6.39 & 7.33 & 122.68 & 0.92 & 7.12 \\
\hline $\begin{array}{c}\mathrm{T}_{7}: \text { Foliar application twice with } \mathrm{ZnO} \\
\text { equivalent to } 0.2 \% \mathrm{ZnSO}_{4}\end{array}$ & 6.02 & 7.17 & 116.89 & 0.85 & 7.00 \\
\hline $\begin{array}{l}\mathrm{T}_{8}: \text { Foliar application twice with } \mathrm{Zn} \text { - } \\
\text { EDTA } \\
\text { equivalent to } 0.2 \% \mathrm{ZnSO}_{4}\end{array}$ & 6.19 & 7.25 & 134.60 & 0.99 & 7.13 \\
\hline SEm \pm & 0.22 & 0.21 & 4.38 & 0.04 & 0.81 \\
\hline C.D. $(P=0.05)$ & 0.69 & 0.66 & 12.72 & 0.12 & 0.25 \\
\hline
\end{tabular}

Table.2 Grain and straw yield of rice during Rabi season as influenced by different NPK combinations [Source: Pasha et al., 2018]

\begin{tabular}{|c|c|c|c|c|c|c|c|c|c|c|c|c|}
\hline \multirow[t]{2}{*}{ Treatment } & \multicolumn{5}{|c|}{ Grain yield ( $t$ ha $\left.^{-1}\right)$} & \multicolumn{5}{|c|}{ Straw yield $\left(\mathrm{t} \mathrm{ha}^{-1}\right)$} & \multirow{2}{*}{$\begin{array}{l}\text { Systemrice } \\
\text { grain } \\
\text { equivalent } \\
\text { yield (t ha- } \\
\text { 1) }\end{array}$} & \multirow{2}{*}{$\begin{array}{c}\text { Sustaina } \\
\text { ble } \\
\text { yield } \\
\text { index } \\
\text { (SYI) }\end{array}$} \\
\hline & $\begin{array}{c}2013 \\
-14\end{array}$ & $\begin{array}{c}2014 \\
-15\end{array}$ & $\begin{array}{c}2015 \\
-16\end{array}$ & $\begin{array}{c}2016 \\
-17\end{array}$ & $\begin{array}{c}\text { Pool } \\
\text { ed } \\
\text { Mea } \\
\text { n }\end{array}$ & $\begin{array}{c}2013 \\
-14\end{array}$ & $\begin{array}{c}2014 \\
-15\end{array}$ & $\begin{array}{c}2015 \\
-16\end{array}$ & $\begin{array}{c}2016 \\
-17\end{array}$ & $\begin{array}{c}\text { Pool } \\
\text { ed } \\
\text { Mea } \\
\text { n }\end{array}$ & & \\
\hline Control & 2.57 & 3.01 & 3.34 & 2.34 & 2.82 & 3.5 & 3.91 & 4.66 & 5.49 & 4.39 & 3.1 & 0.39 \\
\hline $\mathbf{N}$ & 3.13 & 4.00 & 4.61 & 2.61 & 3.59 & 4.05 & 4.85 & 5.29 & 6.04 & 5.06 & 3.97 & 0.45 \\
\hline NP & 3.78 & 4.39 & 4.92 & 3.92 & 4.25 & 4.41 & 5.23 & 5.99 & 6.89 & 5.63 & 4.58 & 0.57 \\
\hline NK & 4.28 & 4.86 & 5.23 & 4.23 & 4.65 & 5.07 & 6.01 & 6.78 & 7.99 & 6.46 & 5.12 & 0.6 \\
\hline NPK & 5.04 & 5.82 & 6.4 & 5.4 & 5.67 & 5.88 & 7 & 7.96 & 9.14 & 7.49 & 6.02 & 0.58 \\
\hline $\mathrm{NPK}+\mathrm{ZnSO}_{4}$ & 5.38 & 6.13 & 6.38 & 5.48 & 5.84 & 6.21 & 6.81 & 7.98 & 8.97 & 7.49 & 6.39 & 0.71 \\
\hline $\begin{array}{l}\text { Farmers } \\
\text { practice }\end{array}$ & 4.07 & 5.46 & 5.91 & 4.91 & 5.09 & 5.02 & 6.77 & 7.68 & 8.6 & 7.02 & 5.69 & 0.54 \\
\hline $\operatorname{SEm}(\square)$ & 0.34 & 0.10 & 0.12 & 0.09 & 0.17 & 0.36 & 0.19 & 0.11 & 0.11 & 0.17 & & \\
\hline $\operatorname{LSD}(0.05)$ & 1.00 & 0.31 & 0.37 & 0.27 & 0.49 & 1.06 & 0.57 & 0.34 & 0.32 & 0.51 & & \\
\hline
\end{tabular}


Table.3 Plant N uptake, nitrogen use efficiency (NUE), nitrogen agronomic efficiency (NAE) and partial factor productivity of applied N (PFPN) under different fertilization treatments ( $\mathrm{Li}$ et al., 2015)

\begin{tabular}{|c|c|c|c|c|c|c|c|c|}
\hline \multirow[t]{2}{*}{$\begin{array}{c}\text { Treatme } \\
\text { nts }\end{array}$} & \multicolumn{2}{|c|}{$\begin{array}{c}\text { N uptake } \\
\left(\operatorname{kg~N~ha}^{-1}\right)\end{array}$} & \multicolumn{2}{|c|}{$\begin{array}{l}\text { NUE } \\
(\%)\end{array}$} & \multicolumn{2}{|c|}{$\begin{array}{c}\text { NAE } \\
\text { (g grain kg-1 } \\
\text { N) }\end{array}$} & \multicolumn{2}{|c|}{ 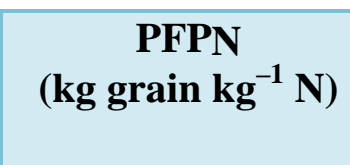 } \\
\hline & 2002 & 2003 & 2002 & 2003 & 2002 & 2003 & 002 & 2003 \\
\hline \multicolumn{9}{|c|}{ Early rice } \\
\hline Control & $\begin{array}{c}42.8 \pm \\
2.0 \mathrm{~d}\end{array}$ & $\begin{array}{c}52.5 \pm 3 . \\
4 \mathrm{c}\end{array}$ & - & - & - & - & - & - \\
\hline NCU-7 & $\begin{array}{c}75.3 \pm \\
3.5 \mathrm{c}\end{array}$ & $\begin{array}{c}85.5 \pm 1 . \\
4 \mathrm{~b}\end{array}$ & $\begin{array}{c}43.3 \pm 3 . \\
4 b\end{array}$ & $\begin{array}{c}44.0 \pm 3 . \\
2 b\end{array}$ & $\begin{array}{l}27.8 \pm 2 \\
.6 \mathrm{~b}\end{array}$ & $\begin{array}{c}14.7 \pm 2 \\
.1 \mathrm{~b}\end{array}$ & $\begin{array}{c}66.7 \pm 3 \\
.6 \mathrm{~b}\end{array}$ & $9.2 \pm 1.1 \mathrm{~b}$ \\
\hline NCU-150 & $\begin{array}{l}89.1 \pm \\
2.8 \mathrm{~b}\end{array}$ & $\begin{array}{c}94.1 \pm 2 . \\
4 a\end{array}$ & $\begin{array}{c}30.9 \pm 1 . \\
7 \mathrm{c}\end{array}$ & $\begin{array}{c}27.7 \pm 2 . \\
4 \mathrm{c}\end{array}$ & $\begin{array}{l}19.9 \pm 1 \\
.1 \mathrm{c}\end{array}$ & $\begin{array}{c}8.6 \pm 2 . \\
3 b\end{array}$ & $\begin{array}{l}39.3 \pm 0 \\
.6 \mathrm{~d}\end{array}$ & $1+3$ \\
\hline $\begin{array}{c}\text { POCU- } \\
75\end{array}$ & $\begin{array}{c}96.0 \pm \\
2.8 \mathrm{~b}\end{array}$ & $\begin{array}{c}100.5 \pm \\
0.7 \mathrm{a}\end{array}$ & $\begin{array}{c}71.0 \pm 4 . \\
1 \mathrm{a}\end{array}$ & $\begin{array}{c}64.0 \pm 5 . \\
0 \mathrm{a}\end{array}$ & $\begin{array}{c}47.4 \pm 0 \\
.9 \mathrm{a}\end{array}$ & $\begin{array}{c}22.3 \pm 3 \\
.4 a\end{array}$ & $\begin{array}{c}86.4 \pm 2 \\
.5 \mathrm{a}\end{array}$ & (1) \\
\hline $\begin{array}{c}\text { POCU- } \\
150\end{array}$ & $\begin{array}{l}113.0 \\
\pm 2.1 \mathrm{a}\end{array}$ & $\begin{array}{c}93.4 \pm 3 . \\
2 \mathrm{a}\end{array}$ & $\begin{array}{c}46.8 \pm 2 . \\
0 b\end{array}$ & $\begin{array}{c}27.3 \pm 4 . \\
3 \mathrm{c}\end{array}$ & $\begin{array}{c}27.6 \pm 2 \\
.3 b\end{array}$ & $\begin{array}{c}7.3 \pm 1 . \\
4 b\end{array}$ & $\begin{array}{c}47.0 \pm 1 \\
.8 \mathrm{c}\end{array}$ & $34.6 \pm 0.2 c$ \\
\hline \multicolumn{9}{|c|}{ Late rice } \\
\hline Control & $\begin{array}{c}38.6 \pm \\
1.3 \mathrm{c}\end{array}$ & $\begin{array}{c}44.6 \pm 2 . \\
4 c\end{array}$ & - & - & - & - & - & - \\
\hline NCU-75 & $\begin{array}{c}62.7 \pm \\
1.2 \mathrm{~b}\end{array}$ & $\begin{array}{c}78.5 \pm 4 . \\
5 b\end{array}$ & $\begin{array}{c}32.2 \pm 1 \\
0 \mathrm{~b}\end{array}$ & $\begin{array}{c}45.2 \pm 4 . \\
2 b\end{array}$ & $\begin{array}{c}10.4 \pm 1 \\
.5 \mathrm{~b}\end{array}$ & $\begin{array}{c}17.4 \pm 2 \\
.8 \mathrm{~b}\end{array}$ & $\begin{array}{c}51.3 \pm 1 \\
.0 \mathrm{~b}\end{array}$ & $4.6 \pm 4.3 \mathrm{~b}$ \\
\hline $\mathbf{N C}$ & $\begin{array}{c}80.8 \pm \\
1.3 \mathrm{a}\end{array}$ & $\begin{array}{c}98.3 \pm 2 . \\
5 \mathrm{a}\end{array}$ & $\begin{array}{c}28.1 \pm 1 . \\
2 b c\end{array}$ & $\begin{array}{c}35.8 \pm 1 . \\
9 \mathrm{~b}\end{array}$ & $\begin{array}{c}10.0 \pm 0 \\
.8 \mathrm{~b}\end{array}$ & $\begin{array}{c}17.0 \pm 1 \\
.6 \mathrm{~b}\end{array}$ & $\begin{array}{c}30.4 \pm 0 \\
.4 \mathrm{c}\end{array}$ & $45.6 \pm 1.2 c$ \\
\hline $\begin{array}{c}\text { POCU- } \\
75\end{array}$ & $\begin{array}{c}80.7 \pm \\
1.3 \mathrm{a}\end{array}$ & $\begin{array}{c}94.6 \pm 5 . \\
2 \mathrm{a}\end{array}$ & $\begin{array}{c}56.2 \pm 1 \\
7 \mathrm{a}\end{array}$ & $\begin{array}{c}66.7 \pm 7 . \\
8 \mathrm{a}\end{array}$ & $\begin{array}{c}17.9 \pm 0 \\
.6 \mathrm{a}\end{array}$ & $\begin{array}{c}35.1 \pm 6 \\
.0 \mathrm{a}\end{array}$ & $\begin{array}{c}58.7 \pm 1 \\
.0 \mathrm{a}\end{array}$ & $2.3 \pm 5.1 a$ \\
\hline $\begin{array}{c}\text { POCU- } \\
150\end{array}$ & $\begin{array}{c}76.8 \pm \\
3.5 \mathrm{a}\end{array}$ & $\begin{array}{c}108.9 \pm \\
3.7 \mathrm{a}\end{array}$ & $\begin{array}{c}25.5 \pm 3 . \\
0 \mathrm{c}\end{array}$ & $\begin{array}{c}42.9 \pm 3 . \\
1 b\end{array}$ & $\begin{array}{c}2.4 \pm 0 . \\
9 \mathrm{c}\end{array}$ & $\begin{array}{c}16.5 \pm 2 \\
.3 \mathrm{~b}\end{array}$ & $\begin{array}{c}22.8 \pm 1 \\
.3 \mathrm{~d}\end{array}$ & $45.1 \pm 1.5 \mathrm{c}$ \\
\hline \multicolumn{9}{|c|}{ Total } \\
\hline Control & $\begin{array}{c}81.4 \pm \\
2.8 \mathrm{~d}\end{array}$ & $\begin{array}{c}97.1 \pm 1 . \\
6 \mathrm{c}\end{array}$ & - & - & - & - & - & - \\
\hline NCU- & $\begin{array}{l}138.0 \\
\pm 4.7 \mathrm{c}\end{array}$ & $\begin{array}{c}164.0 \pm \\
4.7 \mathrm{~b}\end{array}$ & $\begin{array}{c}37.8 \pm 1 \\
5 \mathrm{~b}\end{array}$ & $\begin{array}{c}44.6 \pm 2 . \\
8 \mathrm{~b}\end{array}$ & $\begin{array}{l}19.1 \pm 0 \\
.9 \mathrm{~b}\end{array}$ & $\begin{array}{c}16.0 \pm 1 \\
.0 \mathrm{~b}\end{array}$ & $\begin{array}{c}59.0 \pm 2 \\
.0 \mathrm{~b}\end{array}$ & $9 \pm 1.6 \mathrm{~b}$ \\
\hline NCU-150 & $\begin{array}{l}169.9 \\
\pm 2.8 \mathrm{~b}\end{array}$ & $\begin{array}{c}192.4 \pm \\
4.2 \mathrm{a}\end{array}$ & $\begin{array}{c}29.5 \pm 0 . \\
9 \mathrm{c}\end{array}$ & $\begin{array}{c}31.8 \pm 1 . \\
8 \mathrm{c}\end{array}$ & $\begin{array}{c}15.0 \pm 0 \\
.6 \mathrm{c}\end{array}$ & $\begin{array}{c}12.8 \pm 1 \\
.8 \mathrm{~b}\end{array}$ & $\begin{array}{c}34.9 \pm 0 \\
.3 \mathrm{c}\end{array}$ & $40.7 \pm 1.5 c$ \\
\hline $\begin{array}{l}\text { POCU- } \\
75\end{array}$ & $\begin{array}{l}176.7 \\
\pm 3.2 \mathrm{~b}\end{array}$ & $\begin{array}{c}195.1 \pm \\
5.8 \mathrm{a}\end{array}$ & $\begin{array}{c}63.6 \pm 1 . \\
3 a\end{array}$ & $\begin{array}{c}65.3 \pm 4 . \\
8 \mathrm{a}\end{array}$ & $\begin{array}{c}32.7 \pm 0 \\
.5 \mathrm{a}\end{array}$ & $\begin{array}{c}28.7 \pm 4 \\
.0 \mathrm{a}\end{array}$ & $\begin{array}{c}72.5 \pm 1 \\
.3 \mathrm{a}\end{array}$ & $84.5 \pm 3.5 a$ \\
\hline $\begin{array}{c}\text { POCU- } \\
150\end{array}$ & $\begin{array}{l}189.8 \\
\pm 2.9 \mathrm{a}\end{array}$ & $\begin{array}{c}202.3 \pm \\
5.4 a\end{array}$ & $\begin{array}{c}36.1 \pm 1 . \\
4 b\end{array}$ & $\begin{array}{c}35.1 \pm 2 . \\
3 b c\end{array}$ & $\begin{array}{r}15.0 \pm 0 \\
.9 c\end{array}$ & $\begin{array}{c}11.9 \pm 1 \\
.0 b\end{array}$ & $\begin{array}{c}34.9 \pm 1 \\
.0 \mathrm{c}\end{array}$ & $39.8 \pm 0.8 \mathrm{c}$ \\
\hline
\end{tabular}

Data were means $\pm S E(n=3)$ and different letters $(a, b, c, d)$ within a column refer to significant differences $(P<0.05)$ among treatments in the same rice season. NAE, nitrogen agronomic efficiency; NUE, nitrogen use efficiency; NCU, noncoated urea; $P O C U$, polyolefin-coated urea; $P F P N$, Partial factor productivity of $N$ 
Table.4 Economics of the various treatmnt combinations [Source: Kumar et al., 2017]

\begin{tabular}{|c|c|c|}
\hline Treatments & Net return (Rs. ha $\left.{ }^{-1}\right)$ & B:C ratio \\
\hline No zinc application & 62927 & 1.95 \\
\hline Soil application of the $50 \mathrm{~kg} \mathrm{ZnSO4} \mathrm{ha}^{-1}$ & 82607 & 2.34 \\
\hline Soil application of $\mathrm{ZnO}$ equivalent to $50 \mathrm{~kg} \mathrm{ZnSO} 4 \mathrm{ha}^{-1}$ & 64897 & 1.43 \\
\hline Seedling dip in $10 \mathrm{~kg} \mathrm{ZnSO4}$ slurry ha"-1 & 69037 & 2.10 \\
\hline Seedling dip in $\mathrm{ZnO}$ Slurry equivalent to $10 \mathrm{~kg} \mathrm{ZnSO}_{4} \mathrm{ha}^{-1}$ & 71577 & 2.06 \\
\hline Foliar application twice with $0.2 \% \mathrm{ZnSO4}$ & 72627 & 2.23 \\
\hline Foliar application twice with $\mathrm{ZnO}$ equivalent to $0.2 \% \mathrm{ZnSO} 4$ & 66197 & 1.97 \\
\hline Foliar application twice with $\mathrm{Zn}$ - EDTA equivalent to $0.2 \% \mathrm{ZnSO4}$ & 68297 & 2.01 \\
\hline
\end{tabular}

Table.5 Productivity and profitability of rice-rice cropping sequence as influenced by different NPK combinations [Source: Pasha et al., 2018]

\begin{tabular}{|c|c|c|c|c|c|c|c|}
\hline Year/Treatment & Control & $\mathbf{N}$ & NP & NK & NPK & $\begin{array}{l}\mathrm{NPK}+\mathrm{Zn} \\
\mathrm{SO}_{4}\end{array}$ & $\begin{array}{l}\text { Farmers } \\
\text { practice }\end{array}$ \\
\hline \multicolumn{8}{|c|}{ Productivity (kg ha ${ }^{-1}$ ) } \\
\hline $\begin{array}{c}\text { System Rice Grain } \\
\text { Equivalent Yield }\left(\mathrm{t} \mathrm{ha}^{-1}\right)\end{array}$ & 6.34 & 8.22 & 9.18 & 10.06 & 11.41 & 12.19 & 11.10 \\
\hline $\begin{array}{l}\text { System per day } \\
\text { productivity } \\
\left(\mathrm{kg} \mathrm{ha}^{-1} \text { day }^{-1}\right)\end{array}$ & 17.37 & 22.52 & 25.15 & 27.56 & 31.26 & 33.40 & 30.41 \\
\hline \multicolumn{8}{|c|}{ Cost of Cultivation $\left(\times 10^{3} \mathrm{ha}^{-1}\right)$} \\
\hline 2013-14 & 59.00 & 61.39 & 67.19 & 63.90 & 69.55 & 74.04 & 75.20 \\
\hline 2014-15 & 59.57 & 62.21 & 67.47 & 64.42 & 69.98 & 74.43 & 75.18 \\
\hline 2015-16 & 60.05 & 63.02 & 67.76 & 64.94 & 70.51 & 74.82 & 75.40 \\
\hline 2016-17 & 59.58 & 62.69 & 67.80 & 64.98 & 70.03 & 74.63 & 75.37 \\
\hline Pooled & 59.55 & 62.33 & 67.55 & 64.56 & 70.02 & 74.48 & 75.29 \\
\hline \multicolumn{8}{|c|}{ Gross returns $\left(\times 10^{3} \mathrm{ha}^{-1}\right)$} \\
\hline 2013-14 & 85.40 & 112.10 & 127.04 & 140.50 & 154.20 & 168.29 & 144.19 \\
\hline 2014-15 & 83.38 & 105.87 & 116.52 & 126.97 & 148.78 & 157.51 & 147.02 \\
\hline 2015-16 & 98.19 & 134.06 & 141.12 & 151.40 & 178.35 & 182.20 & 172.04 \\
\hline 2016-17 & 77.05 & 91.20 & 113.53 & 120.11 & 145.14 & 150.95 & 141.76 \\
\hline Pooled & 86.00 & 110.81 & 124.55 & 134.75 & 156.62 & 164.74 & 151.25 \\
\hline \multicolumn{8}{|c|}{ Net returns ( $\left.\times 10^{3} \mathrm{ha}^{-1}\right)$} \\
\hline 2013-14 & 26.40 & 50.71 & 59.85 & 76.61 & 84.65 & 94.25 & 68.99 \\
\hline 2014-15 & 23.81 & 43.67 & 49.05 & 62.55 & 78.80 & 83.08 & 71.84 \\
\hline 2015-16 & 38.14 & 71.04 & 73.36 & 86.46 & 107.84 & 107.38 & 96.64 \\
\hline 2016-17 & 17.47 & 28.51 & 45.73 & 55.13 & 75.11 & 76.32 & 66.39 \\
\hline Pooled & 26.45 & 48.48 & 57.00 & 70.19 & 86.60 & 90.26 & 75.97 \\
\hline \multicolumn{8}{|c|}{ B:C ratio } \\
\hline 2013-14 & 1.45 & 1.83 & 1.89 & 2.20 & 2.22 & 2.27 & 1.92 \\
\hline 2014-15 & 1.40 & 1.70 & 1.73 & 1.97 & 2.13 & 2.12 & 1.96 \\
\hline 2015-16 & 1.64 & 2.13 & 2.08 & 2.33 & 2.53 & 2.44 & 2.28 \\
\hline 2016-17 & 1.29 & 1.45 & 1.67 & 1.85 & 2.07 & 2.02 & 1.88 \\
\hline Pooled & 1.44 & 1.78 & 1.84 & 2.09 & 2.24 & 2.21 & 2.01 \\
\hline
\end{tabular}


Table.6 Economics of different nutrient management strategies in rainfed monsoon rice in two locations (AEZ-25 \& AEZ-11) of Bangladesh [Source: Jahan et al., 2019]

\begin{tabular}{|c|c|c|c|c|c|c|c|c|c|c|c|c|c|c|c|c|}
\hline \multirow[t]{2}{*}{ Treatments } & \multicolumn{2}{|c|}{$\begin{array}{c}\text { Fixed cost } \\
(\text { Rs. ha-1) } \\
1\end{array}$} & \multicolumn{2}{|c|}{$\begin{array}{c}\text { Variable cost } \\
(\text { Rs. ha-1) } \\
2\end{array}$} & \multicolumn{2}{|c|}{$\begin{array}{c}\text { Total cost } \\
\left(\text { Rs. ha }^{-1}\right) \\
3=(1+2)\end{array}$} & \multicolumn{2}{|c|}{$\begin{array}{c}\text { Gross return } \\
(\text { Rs. ha-1) } \\
4\end{array}$} & \multicolumn{2}{|c|}{$\begin{array}{l}\text { Gross margin } \\
\begin{array}{c}(\text { Rs. ha } \\
\text { 5 }=(4-2)\end{array}\end{array}$} & \multicolumn{2}{|c|}{$\begin{array}{c}\text { Net return } \\
\left(\text { Rs. ha }^{-1}\right) \\
\text { 6=(4-3) }\end{array}$} & \multicolumn{2}{|c|}{$\begin{array}{c}\text { BCR } \\
7=(4 / 3)\end{array}$} & \multicolumn{2}{|c|}{$\begin{array}{c}\text { MBCR } \\
\text { (over control) } \\
8\end{array}$} \\
\hline & AEZ-25 & AEZ-11 & AEZ-25 & AEZ-11 & AEZ-25 & AEZ-11 & AEZ-25 & AEZ-11 & AEZ-25 & AEZ-11 & AEZ-25 & AEZ-11 & AEZ-25 & AEZ-11 & AEZ-25 & AEZ-11 \\
\hline HYG & 11141 & 11141 & 4044 & 3974 & 15185 & 15185 & 48750 & 46195 & 44705 & 42221 & 33635 & 31010 & 228 & 216 & 605 & 575 \\
\hline MYG & 11141 & 11141 & 2909 & 2909 & 14050 & 14050 & 40873 & 37680 & 37893 & 34770 & 26752 & 23630 & 206 & 190 & 641 & 585 \\
\hline IPNS & 11141 & 11141 & 4541 & 4400 & 15682 & 15611 & 51091 & 48182 & 46479 & 43711 & 35409 & 32571 & 231 & 219 & 573 & 550 \\
\hline STB & 11141 & 11141 & 3618 & 3477 & 14760 & 14689 & 52085 & 49246 & 48466 & 45698 & 37325 & 34558 & 251 & 238 & 743 & 723 \\
\hline FP & 11141 & 11141 & 1915 & 1490 & 13057 & 12631 & 25900 & 28952 & 24055 & 27462 & 12915 & 16321 & 141 & 162 & 432 & 439 \\
\hline $\mathrm{CON}$ & 11141 & 11141 & $\mathbf{0}$ & $\mathbf{0}$ & 11141 & 11141 & 14334 & 13837 & 14334 & 13837 & 3193 & 2626 & 92 & 88 & $\mathbf{0}$ & $\mathbf{0}$ \\
\hline HYG+CRI & 11141 & 11141 & 4967 & 4896 & 16108 & 16037 & 49175 & 46550 & 44208 & 41654 & 33067 & 30513 & 217 & 206 & 499 & 475 \\
\hline MYG+CRI & 11141 & 11141 & 3760 & 3690 & 14902 & 14902 & 41015 & 38035 & 37325 & 34345 & 26184 & 23133 & 196 & 182 & 506 & 464 \\
\hline IPNS+CRI & 11141 & 11141 & 5463 & 5322 & 16605 & 16534 & 51375 & 48466 & 45840 & 43144 & 34770 & 32003 & 219 & 209 & 478 & 461 \\
\hline STB+CRI & 11141 & 11141 & 4541 & 4400 & 15611 & 15611 & 52368 & 49530 & 47827 & 45060 & 36686 & 33919 & 238 & 226 & 598 & 573 \\
\hline FP'+CRI & 11141 & 11141 & 2625 & 2129 & 13695 & 13340 & 26184 & 29306 & 23630 & 27178 & 12489 & 15966 & 136 & 156 & 326 & 511 \\
\hline $\mathrm{CON}+\mathrm{CRI}$ & 11141 & 11141 & 425 & 497 & 11566 & 11637 & 14476 & 13908 & 14050 & 13411 & 2909 & 2271 & 89 & 85 & 31 & 15 \\
\hline
\end{tabular}




\section{ig.1}

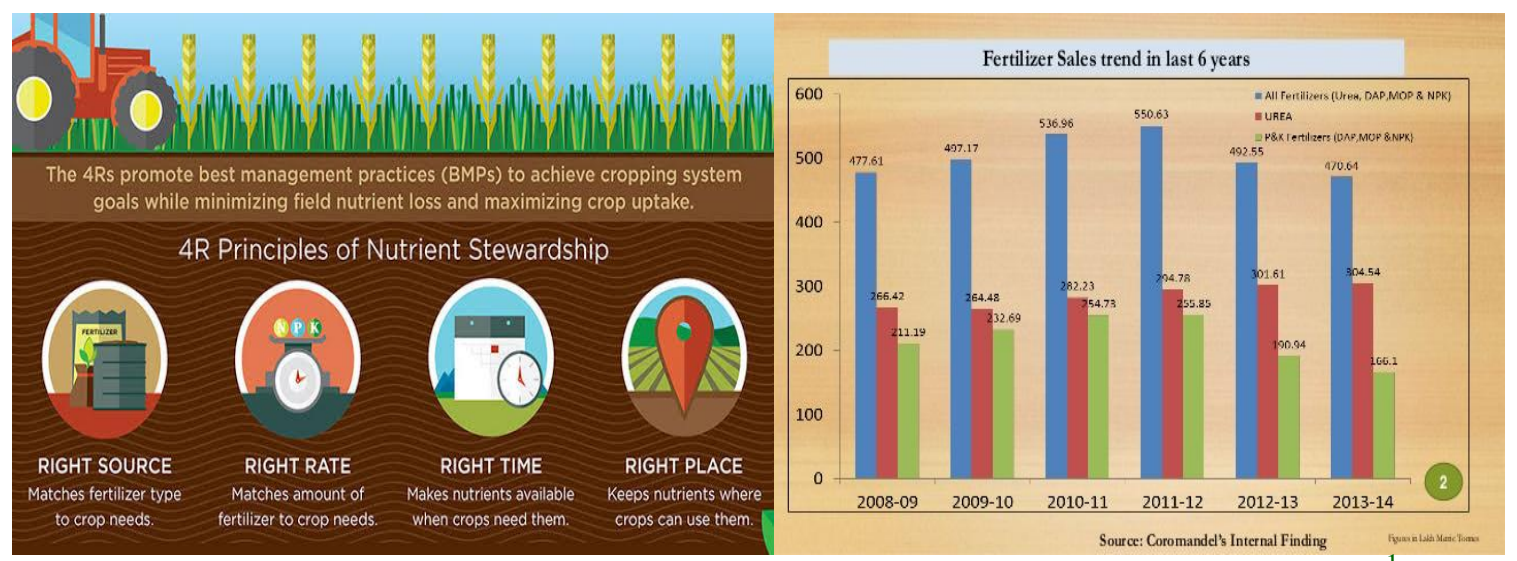

Fig.2 Effect of NPK and Zn on system rice equivalent yield (SREY) $\mathrm{Mg} \mathrm{ha}^{-1}$

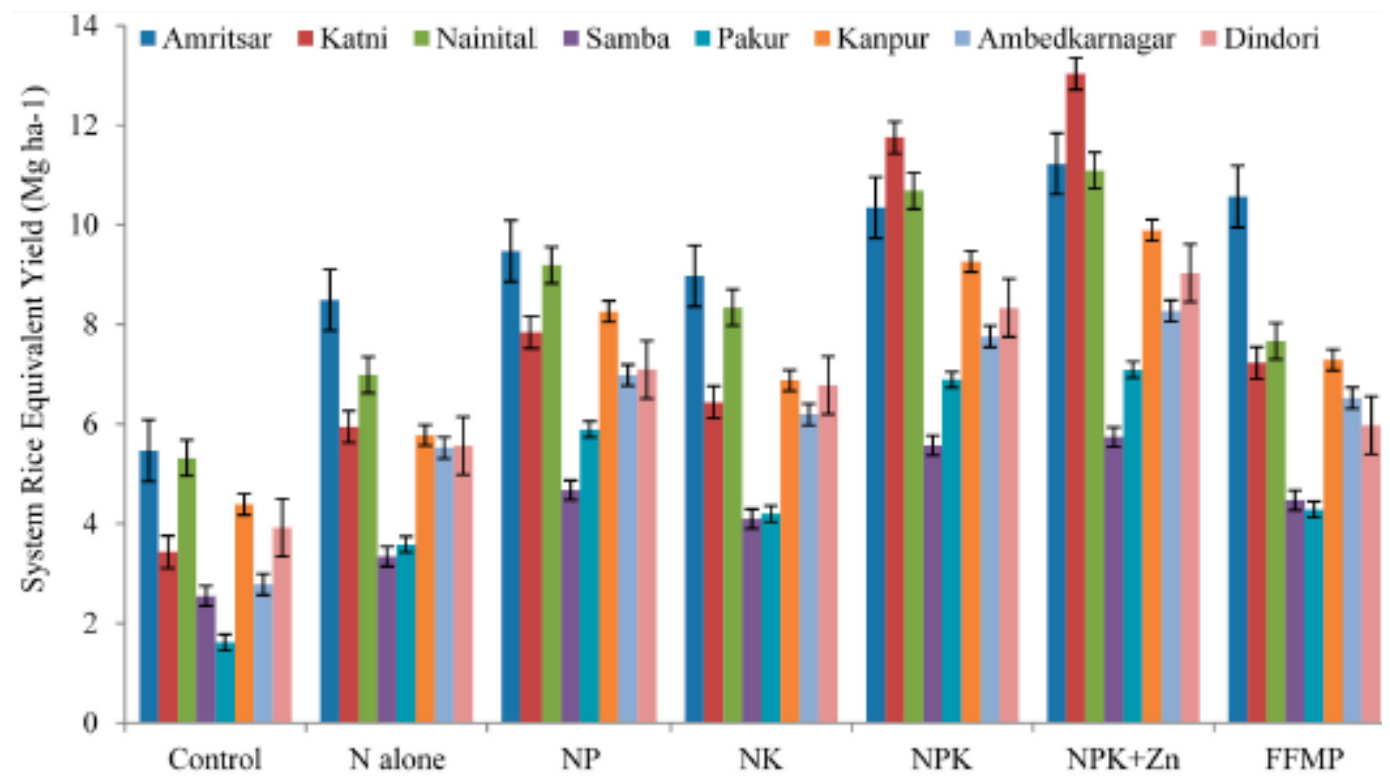

Fig.3 Dry matter $\left(\mathrm{t} \mathrm{ha}^{-1}\right)$ of rice affected by organic fertilizers at the critical growth stages.
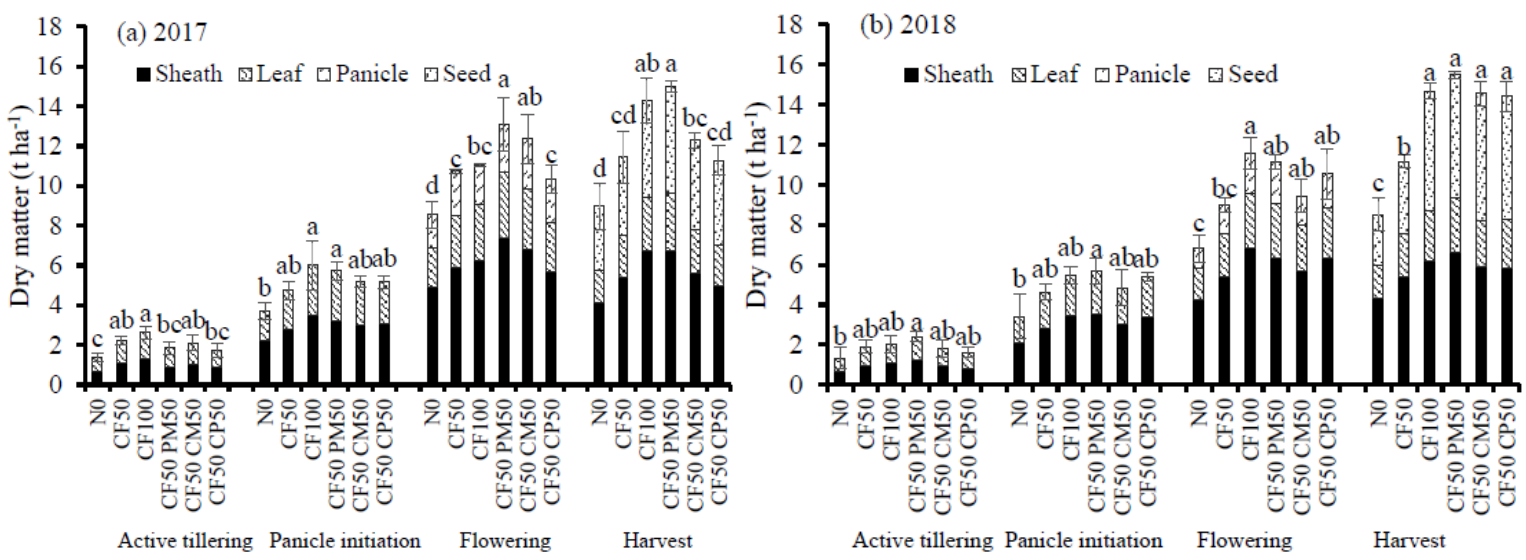
Fig.4

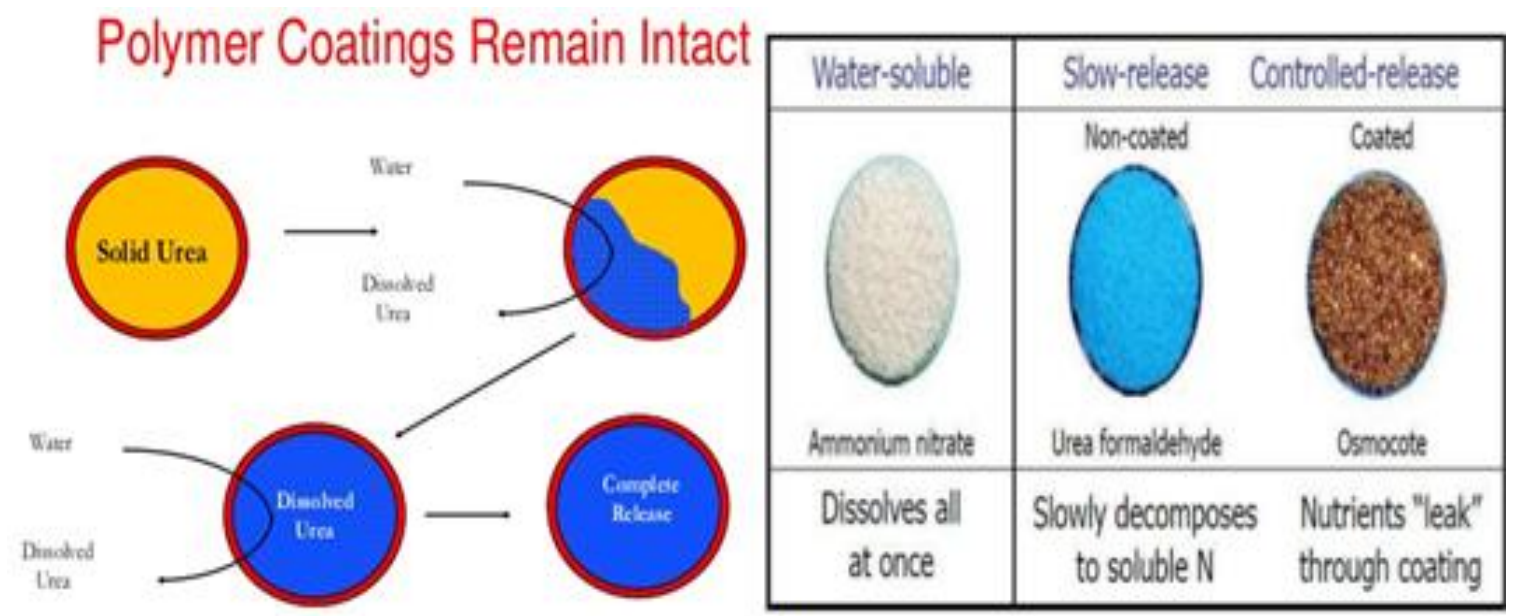

Water soluble Nlow solubility and product with a coated

ENVIRONMENTAL LOSSES OFN

Sulphur Coated Urea

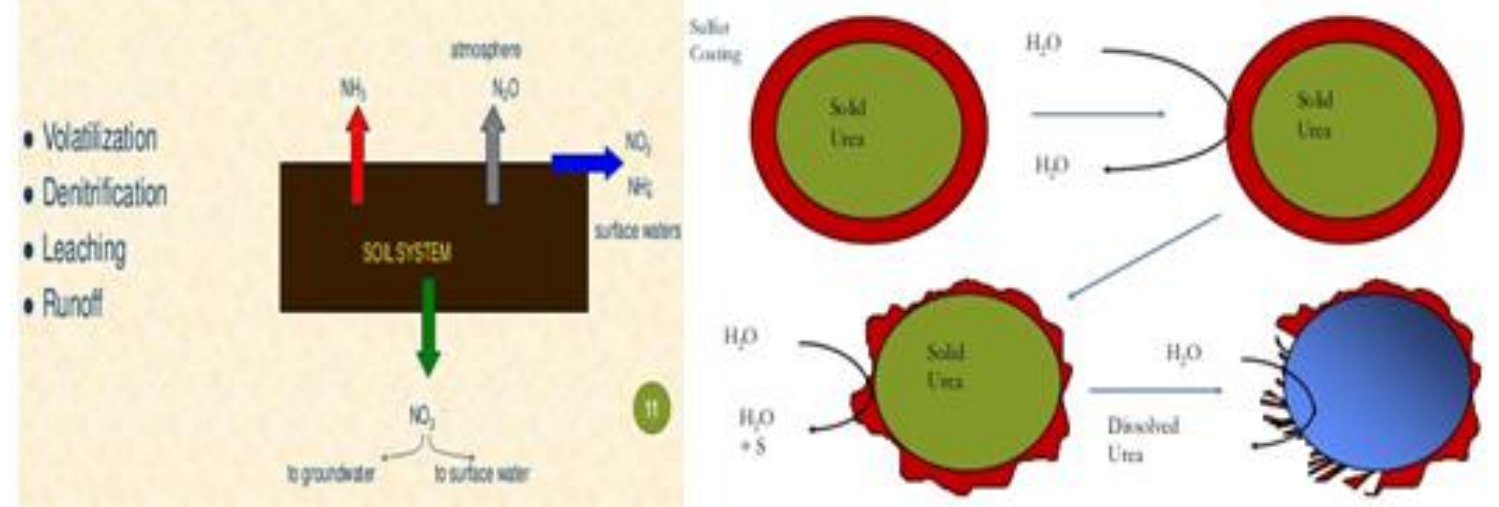

Fig.5(a) The 'ideal fertilizer': the nutrient release is synchronized with the crop's nutrient requirements [Source: Lammel, 2005]

Fig.5(b) Nitrogen leakage in a rice-duck co-culture system with different fertilizer treatments

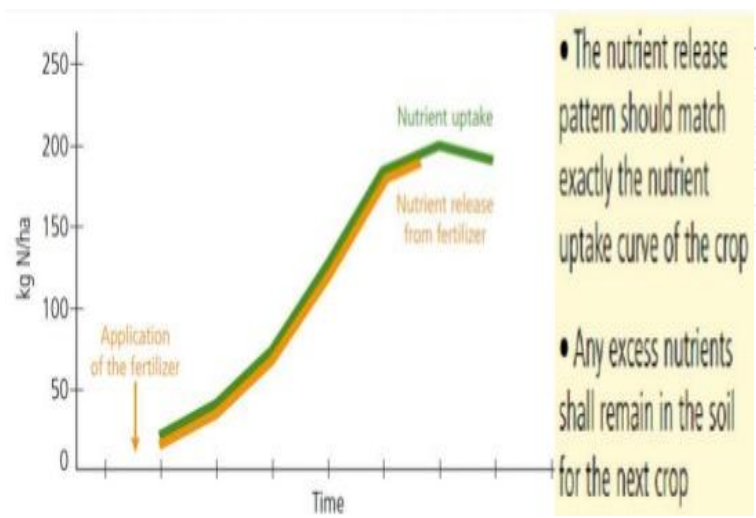

(a)

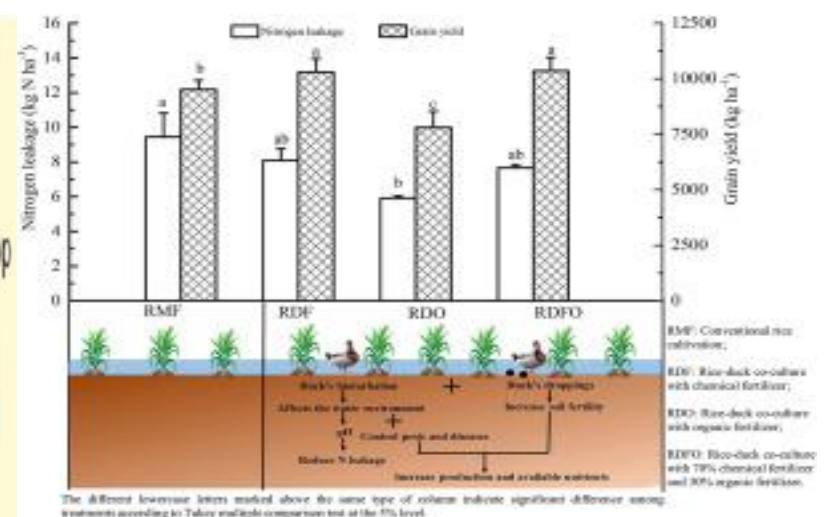

(b) 


\section{Fig.6}

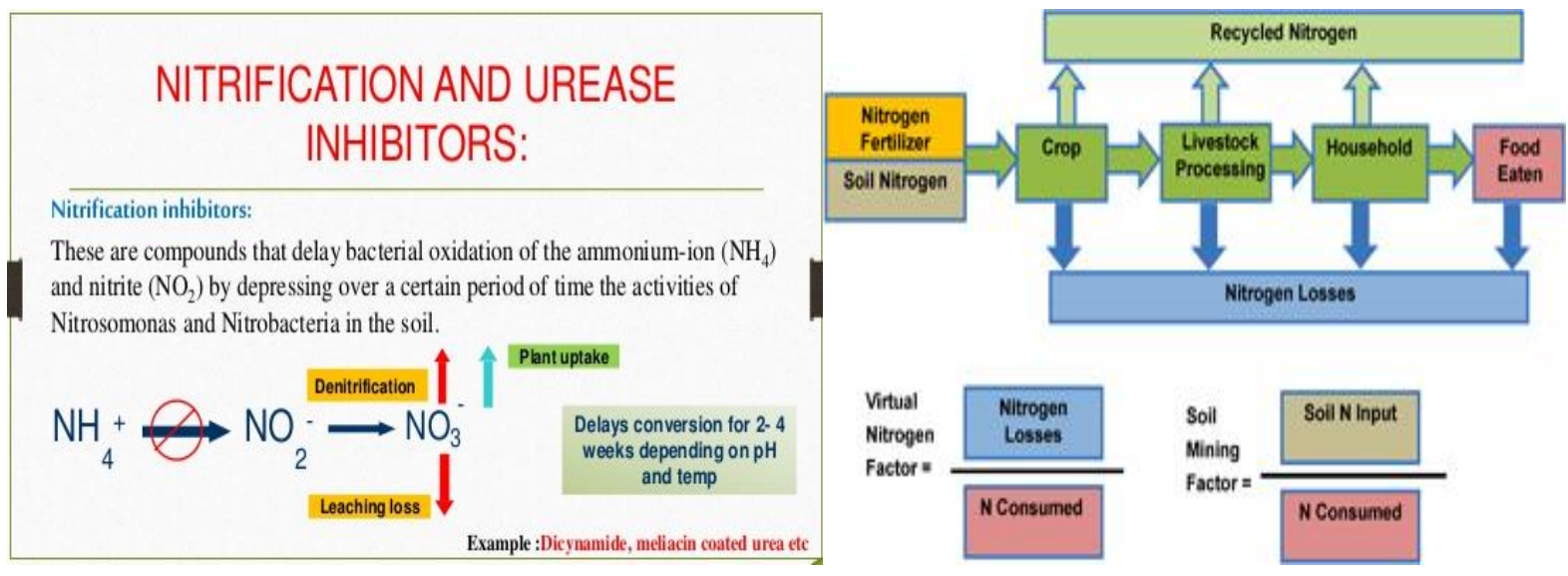

Fig.7 Effect of N application stage and N rate on rice Yield (a), Straw N content (b), Grain N content (c) and Total $\mathrm{N}$ accumulation (d)
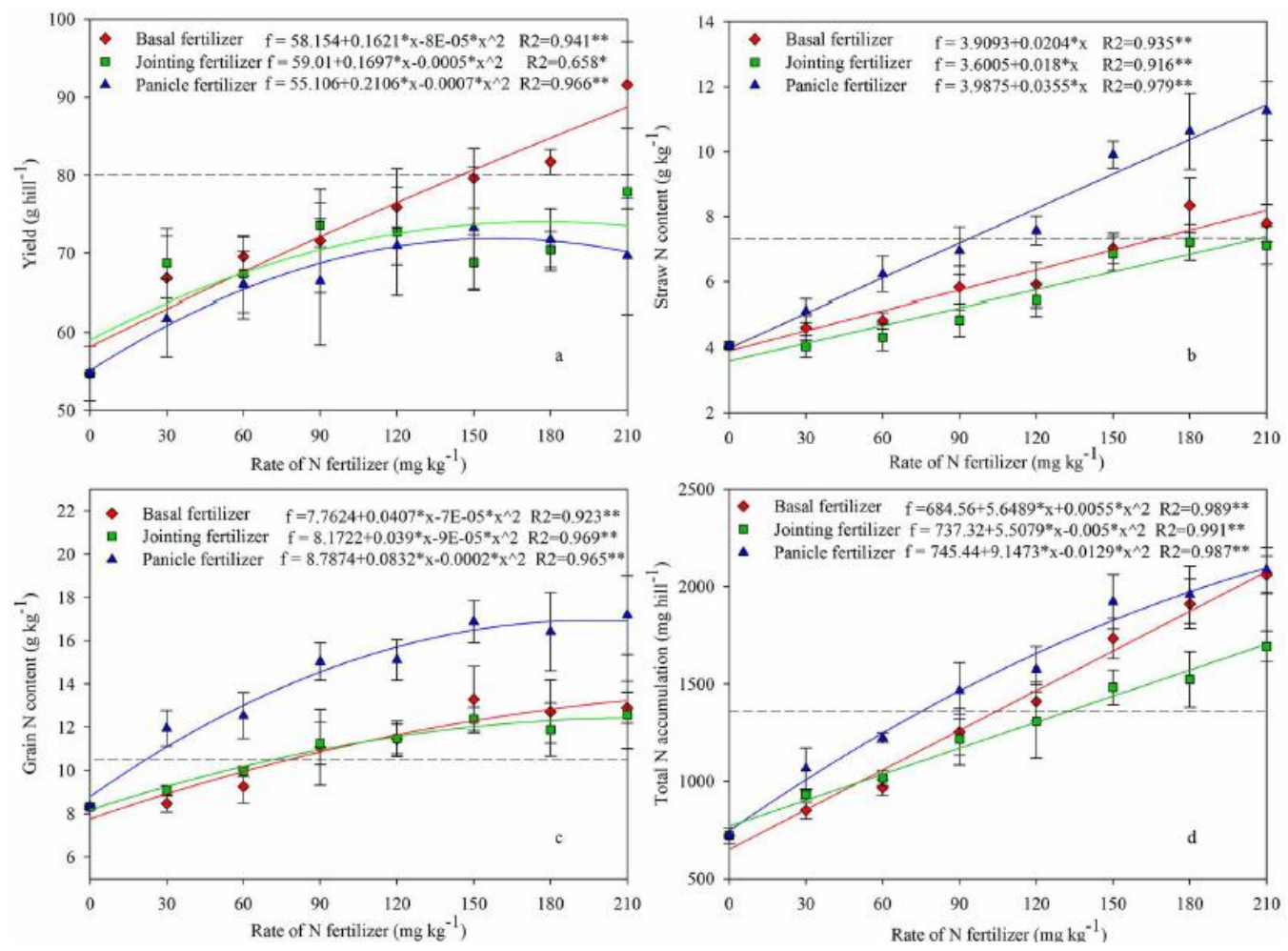
Fig.8 Dry matter production for rice (a) and wheat (b) of the different treatments in the three years

(a)

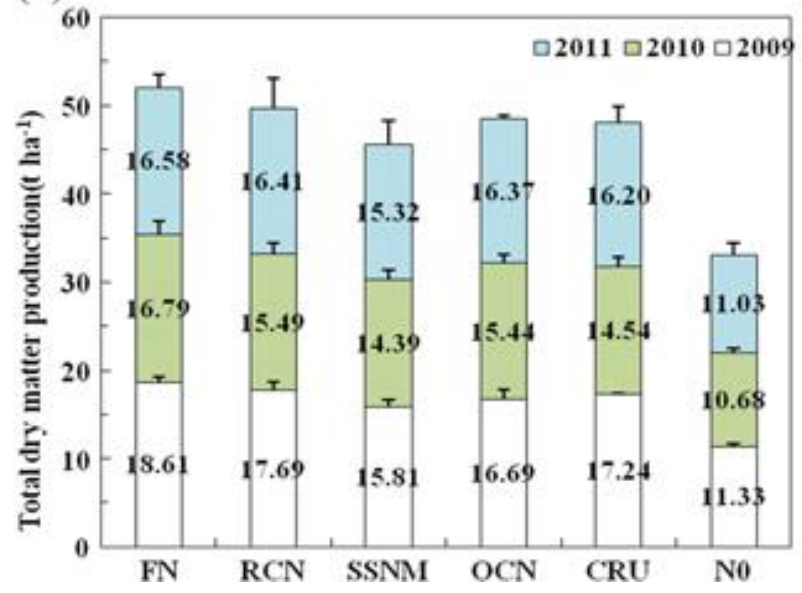

(b)

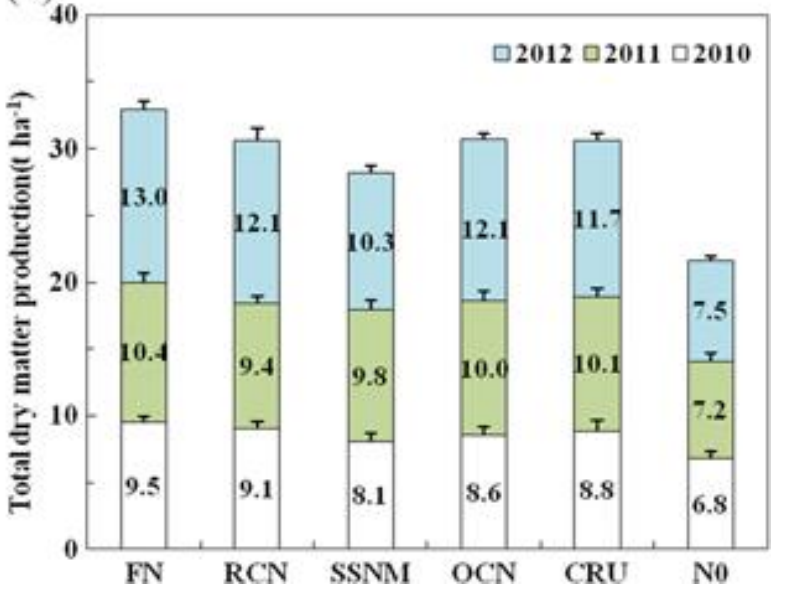

Fig.9 Nitrogen transformations in a submerged soil under lowland rice

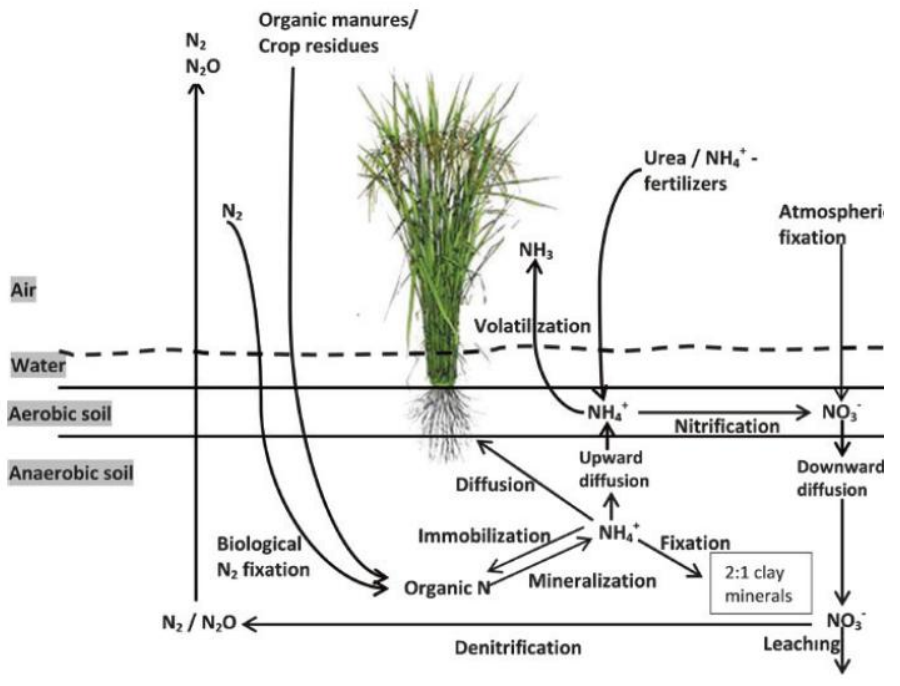

\section{References}

Ali, T.F., 2002. Methods of zinc, iron and manganese application to rice grown under submerged conditions. M.Sc. Thesis, Fac., of Agric., Kafr ElSheikh-Tanta Univ., Egypt.

Anonymous 2018. Agriculture statistics at a glance, Department of Agriculture and Co-operation, Ministry of Agriculture, Government of India, New Delhi.

Babiker, F.S.H. 1986. The effect of zinc sulphate levels on rice (Oryza sativa
L.) growth and productivity. Alexandria J. Agri. Res. 31(1): 48-51.

Badr, M. M. Amany, 2014. Impact of organic and inorganic fertilization, quality of rice and soil fertility. Ph.D.Thesis, Fac. Agric. Kafr El-Sheikh Univ. Egypt

Cakmak, I., 2008. Enrichment of cereal grains with zinc: agronomic or genetic biofortification. Pl. Soil, 30(2): 1-17.

Carreres, R., J. Sendra, R. Ballesteros, E.F. Valiente, A. Quesada, D. Carrasco, F. Leganes and J.G. Cuadra, 2003. Assessment of slow release fertilizers 
and nitrification inhibitors in flooded rice. Biol. Fert. Soils, 39: 80-87

Cassman, K.G., A. Dobermann and D.T. Walters, 2002. Agro ecosystems, nitrogen-use efficiency and nitrogen management. AMBIO, 31: 132-140

Chaudhry, F.M. and Ali, S. 1986. Ripening of rice as influenced by micronutrients $(\mathrm{Zn}, \mathrm{Cu}$ and $\mathrm{Fe})$ when the nitrogen source was ammonium sulphate. Pak. J. Sci. Ind. Res. 29: 120-122.

Chaudhry, F.M. and Wallace, A. 1976. Zinc absorption as affected by iron and chelate of ferrous iron. Plant Soil 45: 697-700.

Chaudhry, F.M., Alarn, A. and Latif, A. 1977. Mechanism of differential susceptibility to two rice varieties to zinc deficiency. Plant Soil 46: 865879.

Chaven, A.S. and Banarjee, N.K.1979. Response of rice to $\mathrm{Fe}-\mathrm{Zn}$ interrelationship in a lateritic soil (Oxisols). Plant Soil 52: 311-313.

Chen, J, Huang Y and Tang Y H 2011 Quantifying economically and ecologically optimum nitrogen rates for rice production in South-Eastern China Agric. Ecosyst. Environ. 142: 195-204

Choudhury, A.T.M. and Kennady, I.R. 2004. Prospects and potential for systems of biological nitrogen fixation in sustamable rice production. Bioferti. Soils.39:217-227.

Datta, S.K., Buresh, I.R.J. and Mamaril, C.P. 2010. Increasing nutrient use efficiency in rice with changing needs. Ferti Res. 26: 157-167

Emilsson, T., J.C. Berndtsson, J.E. Mattsson and K. Rolf, 2007. Effect of using conventional and controlled release fertilizer on nutrient runoff from various vegetated roof systems. Ecol. Eng., 29: 260-271
Esfahani, A.A. 2014. Effect of Fe, Zn and Mn application on growth and yield of rice. Int J Farm Allied Sci, 3(5): 529533.

Ghanem, S.A., Soliman, S.M., Serafy, A.M. and Soaud, A. 1992. Productivity of Broadcasting seeds rice as affected by different application methods of some micronutrients. Proc. $5^{\text {th }}$ Conf. Agron. Zagazig, 1(1): 71-79.

Gomez, K. A. and Gomez, A., 1984, Statistical procedures for Agricultural Research (2/E). John Willey and Sons, New York, pp. 28-33.

Gomez, K. A., 1972. Techniques for field experiments with rice. International Rice Research Institute, Manila, Philippines, pp. 39-45.

Hiremath, S.M. and Hosamani, M.H. 2015. Influence of balanced fertilization on productivity and nutrient use efficiency of maize (Zea mays)-chickpea (Cicer arietinum) cropping systems. Res. Crops 16 (3): 479-84.

Hossain, M.S., Hossain A., Sarkar M.A.R., Jahiruddin M., Teixeira da Silva J.A., Israil Hossain M., 2016. Productivity and soil fertility of the rice-wheat system in the high Ganges River floodplain of Bangladesh is influenced by the inclusion of legumes and manure. Agric. Ecosyst. Environ. 218, 40-52,

Huang, J.L., F. He, K.H. Cui, R.J. Buresh, B. $\mathrm{Xu}$, W.H. Gong and S.B. Peng, 2008. Determination of optimal nitrogen rate for rice varieties sing a chlorophyll meter. Field Crops Res., 105: 70-80

Jahan, M.A.H.S., Hossain A., Sarkar, M.A.R., Teixeira, S.J.A., Ferdousi, M.N.S. 2016. Productivity impacts and nutrient balances of an intensive potato-mungbean-rice crop rotation in multiple environments of Bangladesh. Agric. Ecosyst. Environ, 231(1): 79-97. 
Jahan, M.A.H.S., Timsina, A.H.J., Sarkar, M.A.R. M., Das, S., Chaki, A.K and Hossain, M.M. 2019. Productivity, nutrient balance, and economics of monsoon rice under different nutrient management practices in two agroecological zones of Bangladesh. Open Agriculture 4:24-40.

Jawahar, S., Vijayakumar, D., Bommera, R, Jain, N. 2015. Effect of silixol granules on growth and yield of rice. Int J Curr Res Aca Rev, 3: 168-174.

Kappen, H. 1929. Soil Acidity. Berlin: Springer. (In German)

Keeping M G, Reynolds O L. 2009. Silicon in agriculture: New insights, new significance and growing application. Ann Appl Biol, 155: 153-154.

Khan, A.A. 2008. Effect of Sulphure in Zinc on growth and yield and nutrient uptake of boro rice (cv. BRRI Dhan29). J. Soil Nature; 2(3):10-15.

Khawas, M.A. 1990. Effect of Azotobacterchrooccocum and Azosprillumbrasilience inoculation under graded levels of nitrogen growth and yield of wheat. Plant Soil. 69:6167

Landis, T.D. Dumroese, R.K. 2009. Using polymer coated controlled release fertilizers in the nursery and after outplanting. Forest Nursery Notes, winter.5-12.M.Sc. Thesis, Fac., of Agric., Kafr El-Sheikh-Tanta Univ., Egypt.

Liu X, Wang H, Zhou J, Hu F, Zhu D, Chen Z. 2016. Effect of $\mathrm{N}$ Fertilization Pattern on Rice Yield, $\mathrm{N}$ Use Efficiency and Fertilizer N Fate in the Yangtze River Basin, China. PLoS ONE 11(11): e0166002. doi:10.1371/journal.pone.0166002

MD. L. Pasha, S. Sridevi, M.V.Ramana, P.R. R. Reddy and M. Goverdhan Influence of balanced fertilization on productivity, economics and soil fertility of rice -rice (Oryza sativa L.) cropping system under deccan plateau of Telangana. J Crop Weed, 14(1): 158-162 (2018)

Moe, K., Htwe, A.Z., Thu, T.T.P., Kajihara, Y., and Yamakawa, T. 2019. Effects on NPK Status, Growth, Dry Matter and Yield of Rice (Oryza sativa) by Organic Fertilizers Applied in Field Condition. Agriculture 9, 109; doi:10.3390/agriculture9050109

Moll, R.H., E.J. Kamprath and W.A. Jackson, 1982. Analysis and interpretation of factors which contribute to efficiency of nitrogen utilization. Agron. J., 74: 562-564

Naik, S.K, Das, D.K. 2007. Effect of split application of zinc on yield of rice (Oryza sativa L.) in an inceptisol. Arch. Agron. Soil Sci.; 53:305-313.

Pack, J.E., Hutchinson, C.M., Simonne, E.H. 2006. Evaluation of controlled-release fertilizers for Northeast Florida chip potato production. $J$ Plant Nutr 29:1301-1313

Panse V.G, Sukhatme PV. 1967. Statistical methods for agricultural works. ICAR, New Delhi, Ph.D. Thesis, Fac. Agric. Kafr El-Sheikh Univ. Egypt.

Panwar, A.S., Shamim, M., Subhash Babu, N. Ravishankar, N., Prusty, A.K., Alam, N.M., Singh, D.K., Bindhu, J.S., Kaur, J., and Dashora, L.N. 2019. Enhancement in Productivity, Nutrients Use Efficiency, and Economics of Rice-Wheat Cropping Systems in India through Farmer's Participatory Approach, Sustainability, 11, 122; doi:10.3390/su11010122

Pasha, L., Sridevi, A.S., Ramana, M.V., Reddy, R.R., and Goverdhan, M. 2018. Influence of balanced fertilization on productivity, economics and soil fertility of rice -rice (Oryza sativa L.) cropping system under deccan plateau 
of Telangana. J Crop Weed, 14(1): 158-162

Patil, M.D., B.S. Das, E. Barak, P.B.S. Bhadoria and A. Polak, 2010. Performance of polymer-coated urea in transplanted rice: effect of mixing ratio and water input on nitrogen use efficiency. Paddy Water Environ.,8: 189-198

Peng, S.B, R.J. Buresh, J.L. Huang, X.H. Zhong, Y.B. Zou, J.C. Yang, G.H. Wang, Y.Y. Liu, R.F. Hu, Q.Y. Tang, K.H. Cui and F.S. Zhang, 2010. Improving nitrogen fertilization in rice by site-specific $\mathrm{N}$ management: a review. Agron. Sustain. Dev., 30: 649-656

Prasad, R. And Datt, S.K. 1979. Increasing fertilizer nitrogen efficiency in wetland rice. In: Philippines IRRI (ed) Nitrogen and rice. IRRI, Philippines, pp 465484

Rajini and Sen, A. 2017. Bio- efficiency of polymer coated urea on growth and yield of rice (Oryza sativa L.) under low land cultivation. Int $J$ plant soil sci. 19(1): 1-5.

Sharma, S.K., Jain, N.K. and Upadhyay, B. 2011. Response of groundnut (Arachis hypogeal L.) to balanced fertilization under sub-humid Southern plain zone of Rajasthan. Legume Res., 4:273-77.

Shaviv, A. and R.L. Mikkelsen, 1993. Controlled-release fertilizers to increase efficiency of nutrient use and minimize environmental degradation A review. Nutr. Cycl. Agroeco syst., 35: $1-12$

Shoji, S. and H. Kanno, 1994. Use of polyolefin-coated fertilizers for increasing fertilizer efficiency and reducing nitrate leaching and nitrous oxide emissions. Nutr. Cycl. Agroeco syst., 39: 147-152

Singh, B., and Singh, V.K. 2017.Fertilizer Management in Rice, Chapter.
February 2017DOI: 10.1007/978-3319-47516-5_10

Singh, R. and Sharma, M.P. 1994. Response of rice to different zinc carriers and their method of applications in partially reclaimed salt affected soil. Fertilizer News 39:51- 52.

Soon, Y.K., S.S. Malhi, R.L. Lemke, N.Z. Lupwayi and C.A. Grant, 2011. Effect of polymer-coated urea and tillage on the dynamics of available $\mathrm{N}$ and nitrous oxide emission from Gray Luvisols. Nutr. Cycl. Agroecosys, 90: 267-279

Uddin, M.J., Bhuiya, Z.H., Hoque, M.S. and Rahuman, L. 1981. Effect of rates and methods of zinc application of rice. Madras Agric. J.; 68:211-216.

Varsheny, J.G. 1988. Effect of different micronutrients on the flooded rice in hilly tract of Meghalaya. Oryza 25:2326.

Wang, X.Z., J.G. Zhu, R. Gao, H. Yasukazu and K. Feng, 2007. Nitrogen cycling and losses under rice-wheat rotations with coated urea and urea in the Taihu lake region. Pedosphere, 17: 62-69

Weih, M., L. Asplund and G. Bergkvist, 2010. Assessment of nutrient use in annual and perennial crops: A functional concept for analyzing nitrogen use efficiency. Plant Soil, 339: 513-520

Xu, M.G., D.C. Li, J.M. Li, D.Z. Qin, Y. Hosen, H.P. Shen, R.H. Cong and X.H.He,2013.Polyolefin-coated urea decreases ammonia volatilization in a double rice system of Southern China. Agron. J., 105: 277-284

Xu, M.G., X.F. Sun, C.M. Zou, D.Z. Qin, K. Yagi and Y. Hosen, 2005. Effects and rational application of controlledrelease nitrogen fertilizer in paddy field of southern China. J. Plant Nutr. Fert., 11: 487-493

Yongjie, Yu, Meng $\mathrm{Wu}$, Evangelos Petropoulos, Jianwei Zhang, Jun Nie, 
Yulin Liao, Zhongpei Li, Xiangui Lin and Youzhi Feng,. 2019. Responses of paddy soil bacterial community assembly to different long-term fertilizations in southeast China, Sci Total Enviro., 10.1016/j. scitotenv. 2018.11.359, 656.

Zhang, F.S., J.Q. Wang, W.F. Zhang, Z.L. Cui, W.Q. Ma, X.P. Chen and R.F.
Jiang, 2008. Nutrient use efficiencies of major cereal crops in China and measures for improvement. Acta Pedol. Sin., 45: 915-924

Zhu, Z.L. and D.L. Chen, 2002. Nitrogen fertilizer use in China -Contributions to food production. Nutr. Cycl. Agroecosys, 63: 117-127

\section{How to cite this article:}

Rahul Kumar, Mohan Lal, R. K. Naresh, Mukesh Kumar, Shipra Yadav and Rajendra Kumar, M. Sharath Chandra and Pradeep Rajput. 2020. Influence of Balanced Fertilization on Productivity, Nutrient Use Efficiency and Profitability of Rice in Inceptisol: A Review. Int.J.Curr.Microbiol.App.Sci. 9(01): 568-590. doi: https://doi.org/10.20546/ijcmas.2020.901.063 